\title{
Composition and provenance of the Silurian to Devonian sandstone sequences of the southern Midland Valley, Scotland
}

\author{
E.R. Phillips, H.F. Barron, R.A. Smith \& S. Arkley \\ British Geological Survey, Murchison House, West Mains Road, Edinburgh EH9 3LA \\ (e-mail: erp@bgs.ac.uk)
}

Total number of words: 7301

Synopsis: 186

Figures: 7

Tables: 2

\section{Synopsis}

A provenance study of rocks from the Silurian inliers and Siluro-Devonian Lanark Group sandstones of the southern Midland Valley has shown that they are petrographically and compositionally similar, and were derived from the same source terrane. The clast content of these rocks indicates that before widespread Lower Devonian calc-alkaline volcanism, this source terrane included volcanic and hypabyssal igneous rocks which appear to have been associated with a wacke sandstone-dominated sedimentary sequence and a granitic igneous suite. The possibility that the source rocks for these sequences are within the Midland Valley Terrane, but now not exposed, is discussed. Minor differences in sandstone composition between the Carmichael, Eastfield and North Esk inliers are interpreted as reflecting either slight differences in the source or deposition within individual subbasins. Comparable regional variations within the Swanshaw Sandstone Formation suggest that this sub-basin architecture continued to influence sediment dispersal patterns during the deposition of the basal Lanark Group. The onset of Lower Devonian calc-alkaline volcanism coincided with a major change in sandstone composition within the Lanark Group and accompanied the replacement of the relatively small Silurian sub-basins by a single larger basin. 


\section{Introduction}

The evolution of the Midland Valley Terrane of Scotland during Lower Palaeozoic to Devonian times, and its setting within Caledonian orogenic models has been the focus of continuing debate (Williams \& Harper 1988; McKerrow et al. 1991; Smith 1995; Phillips et al. 1998; Bluck 2000). An important part of this discussion is the sedimentology, structure and provenance of the Silurian sedimentary rocks exposed in a number of inliers in the southern Midland Valley (Fig. 1), and the overlying Siluro-Devonian Lower Old Red Sandstone (LORS) strata of the Lanark Group. In general, the Silurian inliers record the transition from an older, Llandovery, transgressive marine sequence to a younger, Lower Wenlock, regressive terrestrial succession (Cameron \& Stephenson 1985; Robertson 1989; Smith 1995; O’Connor \& Williams 1989). Differences in the thicknesses of the sequences and detailed stratigraphy within the individual inliers (Fig. 2) are thought to reflect their deposition within a number of small sub-basins developed oblique to the Southern Upland Fault during regional sinistral strike-slip (Williams \& Harper 1988; Smith 1995; Phillips et al. 1998). The overlying Lanark Group is dominated by redbed fluviatile sandstones and alluvial fan conglomerates deposited in a linear, northeast-southwest trending basin, the Lanark Basin (Bluck 1978, 1984, 2000).

Earlier provenance studies of the Silurian and Siluro-Devonian sequences within the Midland Valley Terrane have largely concentrated upon the conglomeratic units present within the southern (McGiven 1967; Bluck 1983; Heinz \& Loeschke 1988; Syba 1989) and northern (Bluck 1983; Haughton et al. 1990; Haughton \& Halliday 1991) parts of this terrane. Work on the Silurian rocks in the southern Midland Valley (McGiven 1967; Bluck 1983; Heinz \& Loeschke 1988; Syba 1989) indicates that there is a difference between a southerly derivation direction and the source area presently exposed to the south, i.e. the Southern Uplands Terrane. Similar studies on the Dunnottar and Crawton group conglomerates within the Lower Old Red Sandstone of the north-eastern Midland Valley have identified the presence of a "cryptic" greywacke source within the Midland Valley Terrane (Haughton et al. 1990; Haughton \& Halliday 1991). Until recently, however, no attempt had been made to examine the composition and provenance of the sandstones which dominate the LORS sequences (Phillips et al. 1998). Phillips et al. (1998) demonstrated that the character of the sediment supply changed gradually upward through the LORS sequence of the southern Midland Valley. They found, furthermore, that none of the LORS sedimentary rocks contain detritus that is obviously derived from the Dalradian rocks to the north of the Midland Valley, suggesting that a barrier existed preventing it entering the Lanark Basin.

This paper presents the results of a petrological provenance study of rocks from the Silurian inliers and Lanark Group sandstones. The relevance of these data to the models for Silurian to Devonian basin evolution are discussed, and the possibility that the source rocks for these sequences are within the Midland Valley Terrane, now not exposed, is also investigated.

\section{The Silurian inliers}


Strata of Llandovery and Wenlock age are exposed in several inliers along the southern side of the Midland Valley, namely the Girvan (Main and Craighead), Carmichael, Eastfield, North Esk, Hagshaw Hills and Lesmahagow inliers (Fig. 1). The sedimentary sequences within these inliers record the transition from an older (Llandovery) marine sequence to a younger (Lower Wenlock) terrestrial succession (Cocks \& Toghill 1973; Rolfe 1960, 1961; Rolfe \& Fritz 1966; Cameron \& Stephenson 1985; Robertson 1989; Smith 1995). The present study has focused upon the Silurian sequences exposed within the Hagshaw Hills, Carmichael, Eastfield and North Esk inliers (Fig. 2).

Within the Hagshaw Hills inlier (Fig. 1) the oldest unit, the Smithy Burn Siltstone, includes grey marine siltstones belonging to the upper Llandovery crenulata Biozone. It is followed by the Ree Burn Formation comprising grey mudstones and siltstones that coarsen up to include fine- to mediumgrained wacke sandstones. The overlying Parishholm Conglomerate Formation contains angular to subrounded pebbles of fine-grained acid and basic to intermediate igneous rocks, chert, jasper and quartzite (Paterson et al. 1998). The Douglas Water Arenite, Dovestone Redbed, Fish Bed and Gully Redbed formations are interpreted as having been deposited on a floodplain with semi-permanent lakes that intermittently dried out. Terrestrial plant spores (Wellman \& Richardson 1993; Molyneux 1992) indicate an early Wenlock age for the Fish Bed Formation. The south-easterly derived Hareshaw Conglomerate Formation (McGiven 1967) consists mainly of rounded vein quartz and quartzite pebbles. Subordinate clasts include fine-grained and porphyritic igneous rocks, granite, metamorphic rocks, chert and mudstone. The formation passes up into alluvial sandstones forming the Quarry Arenite Formation.

The Carmichael inlier lies south of Lanark (Fig. 1). At the base of the succession, the Carmichael Burn Formation (Fig. 2) comprises a sequence of shallow marine mudstones, siltstones and minor sandstones from which Rolfe (1960) collected a late Llandovery (crenulata Biozone) fauna. The succeeding fluviatile fine- to coarse-grained pebbly sandstones and conglomerates of the Eastgate Formation include the basal Fence Conglomerate Member which is correlated with the Parishholm Conglomerate (Fig. 2) as it contains predominantly pebbles of igneous rocks, quartzite and chert. The younger Kirk Hill Conglomerate Member (Fig. 2) of the Eastgate Formation contains clasts of mainly igneous material, as well as minor metamorphic and sedimentary rock fragments (Table 1). The sedimentary lithic clasts are petrographically similar to the sandstone that dominates the Eastgate Formation, recording that the sequence was undergoing penecontemporaneous erosion. The Kirk Hill Conglomerate Member has been correlated with the Hareshaw Conglomerate of the Hagshaw Hills. However, the predominance of igneous clasts within the Kirk Hill Conglomerate suggests that a direct correlation is tentative.

In the Eastfield inlier (Figs. 1 and 2) fluviatile sandstones and conglomerates of the March Wood Formation are correlated with Eastgate Formation of the Carmichael inlier (Cameron 1997) and the intercalated mudstones and siltstones near the base of the sequence are interpreted as lacustrine deposits equivalent to the fish beds in the Hagshaw Hills (see Peach \& Horne 1899, p588).

The Llandovery-Wenlock (Molyneux 1996) North Esk Group exposed in the North Esk inlier of the Pentland Hills (Figs. 1 and 2) is at least 2600 m thick. The graptolite-bearing mudstonedominated sequence, with sandy siltstone and very fine-grained sandstone interbeds, that characterises 
the Reservoir Formation is thought to have been deposited in an offshore submarine fan environment (Robertson 1989). Bull (1995), however, suggested that the siltstones and sandstones represent rapid deposition of distal to intermediate storm sands within a low-energy, mud-dominated shelf environment, or of the infilling of a shallow basin. The overlying Deerhope Formation is dominated by finely laminated mudstones and siltstones that probably represent 'overbank' deposits from a turbidity current within a submarine fan setting.

The change in facies to medium- to coarse-grained pebbly sandstones and conglomerates of the Cock Rig Formation (Fig. 2) is the result of deposition in submarine channels within a proximal/inner fan environment. The clast-supported conglomerates contain pebbles of andesitic to rhyolitic igneous rocks, as well as sedimentary rocks. The mudstones, siltstones and fine-grained sandstones of the overlying Wether Law Linn Formation were interpreted by Robertson (1989) as having been deposited in a shallow marine barrier complex.

The Henshaw Formation contains terrestrial sandstones and conglomerates thought to have been deposited in alluvial fans, whilst the finer-grained sedimentary rocks probably reflect deposition within a playa lake (McGiven 1967). Two distinct matrix- to clast-supported conglomeratic units within the formation, the so called 'Igneous' and 'Quartzite' conglomerates, are correlated with the Fence and Kirk Hill conglomerate members, respectively, of the Carmichael inlier (see Fig. 2). The older 'Igneous' Conglomerate is characterized by the presence of very fine-grained, variably porphyritic andesite, dacite and rhyolite, as well as minor quartz-feldspar-biotite-phyric dacite (porphyry), lapilli-tuff, microgranite, trachyte, ignimbrite, tonalite, quartz-diorite and granite pebbles (Table 1). Although, dominated by igneous-derived material, sedimentary (sandstone, siltstone) and metasedimentary (phyllite, meta-quartz-arenite, quartzite, biotite-hornfels) rock fragments are also common (Table 1). Pebbles and cobbles within the 'Quartzite' Conglomerate (early to middle Wenlock) are mainly composed of polycrystalline vein quartz, quartzite and meta-quartz-arenite. However, this heterolithic conglomerate also contains a range of igneous-derived clasts similar to those in the 'Igneous' Conglomerate (Table 1). The rounded nature of the pebbles, which include broken fragments of much larger cobbles, within both of the 'Igneous' and 'Quartzite' conglomerates suggests that they are of polycyclic origin.

\section{Lower Old Red Sandstone Lanark Group}

The Lanark Group (Fig. 2) comprises a terrestrial redbed sequence (?Pridoli-Lower Devonian) of sandstones and conglomerates (Bluck 1978, 1984, 2000; Smith, 1995, Phillips et al. 1998; Browne et al. 2001) with a thick interval of calc-alkaline volcanic rocks (Thirlwall 1981, 1983; Phillips 1994). The predominantly fluvial sandstones and alluvial fan conglomerates were deposited in the linear northeast-trending Lanark Basin (Bluck 1978, 1984). In the Hagshaw Hills (Fig. 2), there is no marked unconformity between the basal Greywacke Conglomerate Formation and the underlying Monkswater Group, but there is a sudden change in depositional facies. The proximal-fan conglomerates are southerly-derived and dominated by clasts of wacke sandstone with some fine-grained igneous rocks and chert (Table 1). The wacke sandstone clasts, although similar to the Southern Uplands sedimentary 
rocks, were thought by Syba (1989) to have been derived from horst blocks of flysch within the Midland Valley Terrane that have subsequently been removed by strike-slip or covered by younger strata.

The overlying high energy fluviatile redbed sandstones of the Swanshaw Sandstone Formation (Fig. 2) form mainly an upward-fining sequence (Smith 1993; 1995). The sandstones that dominate this formation contain small pebbles of andesitic to felsic volcanic rocks, wacke metasandstone, chert, vein quartz and silty mudstone, as well as occasional metasedimentary rock fragments (psammite and quartzite) (Table 1). A renewed input of conglomerate rich in wacke sandstone pebbles in the upper part of the formation (Fig. 2) is thought to record local uplift prior to the LORS volcanism (Smith 1995; Phillips et al. 1998). The overlying calc-alkaline basaltic to andesitic lavas are locally interbedded with poorly sorted volcaniclastic sandstones that contain a restricted clast assemblage dominated by haematised basalt and andesite fragments, indicating that the LORS volcanic rocks were undergoing subaerial penecontemporaneous erosion (Phillips et al. 1998).

The overlying Auchtitench Sandstone Formation (Fig. 2) mainly consists of medium- to coarse-grained volcaniclastic sandstones and conglomerates that were deposited in a fluviatile environment consisting of large, high-energy braided rivers with some proximal deposition from alluvial fans. Southerly derived coarse pebble conglomerates present within the middle of the formation are almost exclusively composed of LORS-type volcanic rock fragments, but may also include minor basaltic andesite, various porphyries, tuffaceous rock and breccia clasts (Phillips et al. 1998). The pebble to boulder content is well-rounded, indicating transport by large rivers flowing across the LORS lava fields that may have extended south of the Southern Upland Fault (Bluck 1983).

\section{Sandstone Petrography}

The present study has focused upon the composition and provenance of the sandstones from the Carmichael, Eastfield and North Esk inliers, as well as the Lanark Group of the southern Midland Valley.

The fine- to coarse-grained sandstones from the March Wood, Eastgate and Henshaw formations are petrographically and compositionally similar (Table 1) and are, in general, poorly to moderately sorted, matrix-poor litharenites with a close to very closely packed clast-supported texture (Fig. 3a). Cementation is mainly due to pressure dissolution of quartz and, to a lesser extent, feldspar. However, traces of quartz, carbonate and/or chloritic cements are locally present. Carbonate was also noted replacing an earlier developed chlorite cement as well as unstable detrital components. Angular, subangular to rarely subrounded detrital grains are mainly of chloritised basaltic to andesitic rock fragments, mono- and polycrystalline quartz as well as plagioclase (Fig. 3a, Table 1). However, sandstones from the Henshaw Formation appear to be slightly more quartzose, being mainly composed of mono- and polycrystalline quartz, as well as variably altered felsitic volcanic rock fragments (Table 1). Sedimentary (mudstone, chert, wacke and quartzose sandstone) and metasedimentary lithic clasts (metasandstone, psammite schist, mica-rich phyllite, quartz mylonite, mylonitic metabasalt) are a minor, but relatively common detrital component within these sandstones. Although dominated by 
basaltic to andesitic volcanic clasts, minor to trace amounts of biotite-phyric dacite, trachyte, hornblende-phyric andesite, rhyolite, microgranitic rock fragments have also been noted. A similar range of igneous-derived lithologies form pebble to cobble sized clasts within the Kirk Hill Conglomerate Member. Accessory detrital components within the sandstones include K-feldspar (including microcline and perthite), opaque minerals, muscovite, biotite, garnet, oxidised biotite, micrographic intergrowths, chlorite, tourmaline, and epidote. Detrital phyllosilicates are locally kinked (probably during compaction) and show a variable shape alignment parallel to bedding.

Although broadly similar to the Carmichael and Eastfield sandstones, the sandstones (Fig. 3b) and microconglomerates (Fig. 3c) of the Cock Rig Formation are slightly coarser grained and contain a wider range of lithologies, forming subrounded to well-rounded granule to pebble sized clasts. These are mainly composed of chloritised basalt, andesite, dacite and rhyolite, but also include feldsparquartz-phyric dacite, plagioclase-phyric andesite, quartz-feldspar-phyric rhyolite (porphyry), microgranite, microdiorite and tonalite; the latter possessing a very well developed micrographic intergrowths. The very fine-grained to glassy volcanic rocks locally possess primary features such as pilotaxitic to hyalopilitic fabrics and/or spherulitic and snow-flake devitrification textures. Sedimentary rock fragments include rare clasts of recrystallised oolitic limestone. Crinoids, shell fragments and ooids have also been recorded within the sandstone matrix to the conglomerates.

The sandstones from the lower part of the Lanark Group are petrographically similar to those from the older March Wood, Eastgate and Henshaw formations. The fine- to coarse-grained sandstones of the Greywacke Conglomerate and Swanshaw Sandstone formations are matrix-poor, heterolithic rocks with a closely to very closely packed clast-supported texture (Fig 3d). Cementation is mainly due to pressure dissolution of quartz, however, traces of quartz and chloritic rim cements have been noted. The sandstones are mainly composed of variably altered, very fine-grained to glassy (devitrified) basaltic to dacitic rock fragments, monocrystalline quartz and plagioclase (Table 1). The finer grained sandstones are typically more quartzose. Minor amounts of sedimentary (sandstone, wacke sandstone, cleaved mudstone, siltstone, chert), metamorphic (mica-rich phyllite, quartz-chlorite-schist) and granitic rock fragments are also present. Accessory detrital components include biotite, muscovite, epidote, chlorite, micrographic intergrowths, tourmaline, zircon, and chloritic pseudomorphs after detrital ferromagnesian minerals. Detrital phyllosilicates locally exhibit a preferred alignment parallel to bedding. Microconglomerates from the Greywacke Conglomerate Formation are characterised by rounded pebbles and granules of fine-grained wacke sandstone and coarse-grained siltstone. Other lithologies include chloritised basalt, mudstone, chert, polycrystalline vein quartz, quartzite, finegrained limestone and felsite.

The Auchtitench Sandstone Formation, that forms the remainder of the Lanark Group (Fig. 2), is petrographically distinct and comprises a sequence of fine- to coarse-grained, moderately to poorly sorted, closely packed lithic-rich, quartzose to slightly feldspathic sandstones (Fig. 3e). These litharenites to quartzose litharenites are mainly composed of angular to occasionally subrounded clasts of basaltic to dacitic rock fragments with variable amounts of mono- and polycrystalline quartz and plagioclase (Table 1). Minor to rare sedimentary and metasedimentary (greenschist facies) rock fragments are locally present. Accessory detrital components include K-feldspar, epidote, garnet, 
opaque minerals, chlorite, muscovite, amphibole, rutile and chloritic pseudomorphs after detrital ferromagnesian minerals. In the more lithic-rich, volcaniclastic sandstones, such as those of the Wiston Grey Volcaniclastic Member of the Auchtitench Sandstone Formation, the detrital assemblage is dominated by fine- to very fine-grained, variably haematised basalt and andesite rock fragments. These rock fragments are petrographically similar to, and are believed to have been derived from, the LORS volcanic rocks.

\section{Provenance}

Modal compositional data has been obtained for medium- to coarse-grained sandstones from the Silurian Carmichael, Eastfield and North Esk inliers, as well as the Lanark Group of the Ayr, Lanark, Hamilton and New Cumnock districts. Sandstone compositions were calculated as volumetric proportions of the following categories of detrital grains (after Dickinson \& Suczek 1979): stable quartz grains (Q) including both mono- (Qm) and polycrystalline (Qp) quartz; monocrystalline feldspar (F) grains including plagioclase (Pl) and K-feldspar (Ksp); unstable polycrystalline lithic fragments (L) of three main types, namely volcanic (Lv), metamorphic (Lm) and sedimentary (Ls) rock fragments. The total lithic component (Lt) of the sandstones represents the sum of the unstable lithic fragments (L) plus stable polycrystalline quartz (Qp) grains. The matrix and primary cement, as well as degraded, unstable detrital material where the clast shape can no longer be recognised (i.e. secondary matrix component) have been included within the 'matrix' component. Other minor components include opaque minerals (Op), carbonate cement (CC) and granitic lithic clasts (Lg). Representative compositional data are listed in Table 2 and plotted graphically on Figs. 4 to 7.

Sandstones from the Cock Rig, Henshaw, March Wood, Eastgate, Greywacke Conglomerate and Swanshaw Sandstone formations all show varying degrees of compositional overlap (Figs. 4, 5 and 7) this suggests that the Silurian successions in the inliers and in the lower part of the overlying Lanark Group were probably derived from the same or a similar source. Quartz-feldspar-lithic and monocrystalline quartz-feldspar-total lithic plots (Fig. 6, after Dickinson \& Suczek 1979) indicate that this was a recycled orogenic source, an interpretation supported by the presence of metamorphicderived detritus within the clast assemblage (Fig. 4d, also see Tables 1 and 2). The slightly higher feldspar and quartz contents of the Eastgate and Swanshaw Sandstone formations suggesting a more mixed to volcanic-related provenance for these sandstones (Fig. 6b). However, the clustering of the data and absence of any significant trends on Figs. 4 and 5 suggests that the sediment supplied during the deposition of the Silurian inliers and basal Lanark Group sequences was well 'mixed' and derived from a single source terrane. Detailed examination of the data has revealed minor differences in sandstone composition, in particular between unstable lithic and quartzose components in the Eastgate (Carmichael inlier), March Wood (Eastfield inlier), Henshaw and Cock Rig (North Esk inlier) formations (Figs. 4c, d and 5a to c). These variations may indicate localised changes in the composition of the source terrane, variation in the sedimentary processes (degree of reworking, length of transport) active within the individual Silurian sub-basins or both. Comparable differences in sandstone composition have also been recognised between the Swanshaw Sandstone Formation from the Lanark, 
New Cumnock and Ayr districts. In addition Swanshaw Sandstone Formation sandstones show an upwards increase in the modal proportions of volcanic and wacke sandstone clasts towards the base of the LORS volcanic formations, possibly recording uplift prior to the onset of volcanism (Phillips et al. 1998).

Sandstones interbedded with the LORS volcanic rocks and those of the overlying Auchtitench Sandstone Formation are compositionally distinct from the sequences in the Silurian inliers and Swanshaw Sandstone Formation, and show a much greater range in composition (Figs. 4, 5 and 7). The volcaniclastic or more quartzose litharenites from the Auchtitench Sandstone Formation and LORS volcanic formations (e.g. Duneaton and Biggar volcanic formations) lie along the same trend shown as a solid line on Figs. 4 and 5. The systematic variation in volcanic lithic fragments, plagioclase and monocrystalline quartz in these sandstones may reflect either: (a) an increase in the maturity of the sandstones, leading to an increase in the stable quartzose component; or (b) the mixing of detritus from two separate sources. The ternary plots on Fig. 6 indicate that the Auchtitench Sandstone Formation and associated volcaniclastic sandstones were mainly derived from a volcanic source; namely the LORS volcanic rocks. However, in detail, the data define a trend from undissected, through dissected volcanic source, into a more mixed/recycled orogenic provenance. This more complex provenance for the Auchtitench Sandstone Formation was interpreted by Phillips et al. (1998) as recording the mixing of detritus derived from both volcanic and mixed or recycled orogenic sources. Phillips et al. (1998) identified a number of 'cycles' within the Auchtitench Sandstone Formation characterised by an increase in quartz and plagioclase, and an antithetic decrease in the modal proportion of volcanic lithic clasts (Fig. 7). They concluded that this cyclicity reflects periods of uplift and erosion within the LORS volcanic source terrane located to the south, each event resulting in an initial increase in volcanic detritus, which is gradually replaced by a return to the background more quartzose sediment supply. The latter may derive from a wider regional source in contrast to the more locally derived, and generally coarser grained, igneous clasts.

\section{Discussion}

Analysis of the composition and provenance of the Lanark Group and sandstones sequences within the Silurian inliers of the southern Midland Valley has yielded results which have implications for any model of evolution for the Midland Valley of Scotland during late Silurian to early Devonian times.

The sandstones from the Cock Rig, Henshaw, March Wood, Eastgate, Greywacke Conglomerate and Swanshaw Sandstone formations are compositionally similar (Figs. 4, 5 and 7) and share the same recycled orogenic provenance (Fig. 6). Consequently, although the Greywacke Conglomerate Formation represents a significant change in depositional environment at the base of the Lanark Group, this did not reflect a major change in sandstone provenance between the Silurian strata and overlying basal Lanark Group. The minor differences in sandstone composition between the clastic sequences within the Carmichael, Eastfield and North Esk inliers (Figs. 4 and 5) may indicate localised changes in the composition of the source terrane, or alternatively, reflect their deposition within 
individual sub-basins. Importantly, comparable regional differences in sandstone composition have also been recognised within the Swanshaw Sandstone Formation (Figs. 4 and 5). This may be used to suggest that the sub-basin architecture which developed earlier during the Silurian (Williams \& Harper 1988; Smith 1995) was maintained and continued to influence sediment dispersal during the initial deposition of the Lanark Group. This interpretation is supported by lithostratigraphical and sedimentological evidence (Smith 1995) that indicates that there is no major break in sedimentation at the base of the Lanark Group. A major change in sandstone composition and, hence, provenance occurs within the Lanark Group, and coincides with the onset of Lower Devonian calc-alkaline volcanism. This volcanic episode was followed by the deposition of the Auchtitench Sandstone Formation with the Lower Devonian basaltic to andesitic lavas providing the main source of detritus. The absence of any obvious regional variations in sandstone composition within the Auchtitench Sandstone Formation suggests that the influence of the sub-basins had by this time been removed. It is likely that calcalkaline volcanism accompanied a phase of extension or transtension which led to a major change in basin architecture and the replacement of the relatively small Silurian sub-basins by the larger single Lanark Basin.

The overall age and location of the recycled orogenic provenance of the sandstone-dominated sequences of the Silurian inliers and Siluro-Devonian of the southern Midland Valley remains uncertain. Previous studies have all concluded that the Southern Uplands Terrane was not the source of sedimentary and igneous detritus within the major conglomeratic deposits, e.g. Greywacke Conglomerate Formation (McGiven 1967; Bluck 1983, 1984; Syba 1989; Smith 1995). However, Bluck (2000) reported preliminary work indicating that the clasts within the Greywacke Conglomerate Formation are petrographically similar to those present within the Lower Devonian Great Conglomerate Formation (Browne et al. 2001). The southerly derived Great Conglomerate Formation rests unconformably on the Lower Palaeozoic strata of the northeastern Southern Uplands and pebbles are mainly composed of wacke sandstone as well as chert, quartzite and igneous rocks, such as altered diorite, quartz-porphyry and felsite (McAdam \& Tulloch 1985; Davis et al. 1986). McAdam \& Tulloch (1985) concluded that the Great Conglomerate Formation was derived from the surrounding Lower Palaeozoic rocks. However, the relationship of this formation to the Lanark Group of the southern Midland Valley is uncertain, as these two formations are separated by the Southern Upland Fault. Consequently, the contention that the Southern Uplands Terrane represents the primary source for the sequences within the Silurian inliers and Siluro-Devonian Lanark Group remains unproven.

The clast content of the Silurian and earliest Siluro-Devonian rocks indicates that even before the widespread Lower Devonian calc-alkaline volcanism, the source terrane included volcanic and hypabyssal igneous rocks that appear to have been associated with a granite/granodiorite/tonalite suite. Geochemical studies (Heinz \& Loeschke 1988) indicate that these fine-grained igneous rocks belong to calc-alkaline to high-K suites and thus may have been associated with a convergent plate margin, or continental area undergoing crustal extension. The sedimentary and very low-grade metasedimentary clasts present within the sandstones and conglomerates range from wacke sandstones, quartz arenites and cherts to limestones. This assemblage implies that detritus fed to the Midland Valley Silurian and Lanark Group basins may have been supplied from a volcanic arc, founded upon an older metamorphic 
basement. This volcanic terrane was associated with, or covered by a wacke sandstone-dominated sedimentary sequence that also included minor shelf limestones. In the southern Midland Valley this source may be cryptic and covered by younger rocks, overthrust by the Southern Uplands Terrane, or removed by sinistral strike-slip along the line of the present Southern Upland Fault. A cryptic southerly provenance, comprising high-level granitoids intruded into litharenites and wacke sandstones, has also been suggested for the southerly derived conglomerates within the Crawton Group of the northeastern Midland Valley (Haughton 1988). These conglomerates also contain first cycle, angular to subrounded clasts and boulders (up to $1 \mathrm{~m}$ diameter) of granitic rocks that were probably derived proximally from a source within the Midland Valley (Haughton 1988), rather than one south of the present Midland Valley Terrane (Armstrong \& Owen 2000). Importantly, the sedimentary rocks within the cryptic source are isotopically distinct from those of the Southern Uplands to the south and Dalradian to the north (Haughton 1988).

Metamorphic detritus (greenschist to amphibolite facies) is a common minor component within the Silurian and Siluro-Devonian sandstones and conglomerates of the southern Midland Valley. Whereas the Siluro-Devonian strata of the northern Midland Valley contains conglomerates and sandstones which are clearly derived from the Grampian Terrane and Highland Border Complex (Haughton \& Bluck 1989; Phillips et al. 1998), no unambiguous clastic material from either of these sources is known from the southern part of the Midland Valley. This supports a model in which the Lanark basin and the basins in the northern Midland Valley were separate during the late Silurian to early Devonian times. Haughton (1988) and Haughton et al. (1990) demonstrated that the cryptic source within the central part of the Midland Valley Terrane, which supplied material to the southerly derived Crawton Group conglomerates, also included a block of older ( $>440 \mathrm{Ma}$ ) metamorphic rocks. Haughton et al. (1990) suggested that the uplift of this metamorphic terrane, which included rocks up to staurolite facies, coincided with emplacement of a suite of late Silurian to early Devonian (c. 415 Ma) granitoids and related hypabyssal intrusions (found as clasts within the Crawton Group conglomerates). However, the presence of a similar range of lithologies within both the Silurian and Siluro-Devonian sequences of the southern Midland Valley suggests that this metamorphic source may have been available much earlier than previously thought (Llandovery/Wenlock).

Rare limestone clasts within the Crawton Group conglomerates contain early Ordovician silicified brachiopod and crinoid remains (Ingham et al. 1985), and probable mid-Ordovician conodonts (Armstrong \& Owen 2000). Mid-Ordovician conodonts (Pygodus anserinus Biozone) also occur within sparse limestone pebbles within channel conglomerates within the Swanshaw Sandstone Formation (Armstrong \& Owen 2000; Smith 2000; Dean 2000) and Greywacke Conglomerate Formation (Armstrong \& Owen 2000). The evidence of derived fossils, therefore, places an age constraint on at least part of the sedimentary component of the source terrane as mid-Ordovician. As the Dounans limestone within the Highland Border Complex is mid-Arenig (Ingham et al. 1985), and lacks conodonts it cannot form the source of the limestone clasts within either the Crawton or Lanark groups (cf. Armstrong \& Owen 2000). Conodont colour alteration values for these assemblages indicate that they have been affected by localised heating and are, therefore, not simply derived from the Stinchar Limestone at Girvan (Armstrong \& Owen 2000). 
Northerly-derived conglomerates within the Ordovician sequence around Girvan contain pebbles and boulders of granite as well as rhyolite, andesite, basalt, porphyries, and metamorphic rocks. The granite clasts range in age from 590 to 450 Ma (Longman et al. 1982), with the younger granite boulders (451 $\pm 8 \mathrm{Ma}$, Longman et al. 1982) being not much older than the formations in which they occur. The conglomerates are interpreted as recording the unroofing of a Cambro-Ordovician igneous complex, possibly intruded into an older metamorphic basement (pre-593 \pm 28 Ma, Longman et al. 1982), which lay immediately to the northwest within the Midland Valley Terrane (Bluck 1984; Phillips et al. 1998). Comparable ages have been determined for granitic clasts from north-westerly derived conglomeratic units within the Ordovician northern belt of the Southern Uplands terrane (450480 Ma, 550-650 Ma; Elders 1987), leading Smith et al. (2001) to suggest that the Midland Valley source terrane also supplied material into the Southern Uplands basin. On the basis of a study of detrital garnets and mica radiometric ages, Hutchison \& Oliver (1998) concluded that the Grampian Terrane provided a source for detritus carried by rivers across the Midland Valley Terrane and into the Southern Uplands basin during Upper Ordovician times. Almandine-rich garnet, however, is common within many regionally metamorphosed terranes and, therefore, does not provide unequivocal evidence for the Grampian Terrane being the source of this detritus. Sm/Nd isotopic provenance studies (Evans et al. 1991) have not found any evidence for a Dalradian source having contributed detritus to the Northern Belt of the Southern Uplands. Furthermore, recent work (Phillips et al. 2003) dating detrital zircons from the wacke sandstones (Portpatrick Formation) from the Northern Belt indicate a more complex provenance, including an Avalonian, rather than Laurentian, source for at least some of the detritus being supplied to the Southern Uplands basin.

A range of rocks with an igneous and metamorphic provenance remarkably similar to those included within the Silurian and basal Lanark Group sedimentary sequences are present within the Tyrone Igneous complex (Daly 1996) and its Ordovician cover. This potential source terrane lies within an extension of the Midland Valley Terrane in Ireland and comprises: (1) high-grade (garnet \pm sillimanite) metasedimentary rocks; (2) an ophiolitic complex obducted during the Arenig to Llanvirn (c. 472 Ma, Hutton et al. 1985); and (c) an Arenig-Llanvirn volcanic suite (including basaltic andesite, dacite and rhyolite). These volcanic rocks are intruded by calc-alkaline granites, granodiorites, diorite, granophyres, tonalites and quartz-feldspar porphyries. It is concluded, therefore, that the most likely source for the Lanark Group and underlying Silurian sedimentary sequences lay within the Midland Valley Terrane. Fragments or slivers of this source were juxtaposed between the Midland Valley and Southern Uplands terranes as they were transported, by strike-slip, along the Laurentian continental margin during late Silurian to early Devonian times.

\section{Conclusions}

The sandstone-dominated sequences in the Silurian inliers and the lower part of the SiluroDevonian Lanark Group of the southern Midland Valley are petrographically and compositionally similar, and share the same provenance. Although the alluvial fan conglomerates of the Greywacke Conglomerate Formation represent a significant change in depositional environment, they do not 
denote a major change in sandstone provenance between the Silurian sequences and overlying Lanark Group. Minor differences in sandstone composition between the Carmichael, Eastfield and North Esk inliers are interpreted as reflecting their deposition within individual sub-basins. Comparable regional variations in sandstone composition within the Swanshaw Sandstone Formation suggest that this subbasin architecture continued to influence sediment dispersal during deposition of the basal Lanark Group. The onset of Lower Devonian calc-alkaline volcanism coincided with a major change in sandstone composition and the replacement of the relatively small Silurian sub-basins by a single larger basin; the Lanark Basin.

The range of lithologies present as clasts in Silurian and Lanark Group sedimentary rocks implies that they were derived by erosion of a volcanic or igneous complex (possibly CambroOrdovician in age) with an associated sedimentary (mid-Ordovician) cover and founded upon an older metamorphic basement. This source terrane may be concealed within the Midland Valley or occur as slivers between the Midland Valley and Southern Uplands terranes, introduced by sinistral strike-slip along the Laurentian continental margin during late Silurian to early Devonian.

\section{Acknowledgements}

This work forms part of the Midland Valley Regional Mapping Programme presently being undertaken by the British Geological Survey. We would like to thank Maxine Akhurst and Alison Monaghan for their comments on an earlier version of this manuscript. Brian Bluck and Colin Braithwaite are acknowledged for their constructive reviews of this paper. This paper is published with the permission of the Executive Director of the British Geological Survey (National Environmental Research Council).

\section{References}

Armstrong, H. \& Owen, B. 2000. Age and provenance of limestone clasts in Lower Old Red Sandstone conglomerates: implications for the geological history of the Midland Valley Terrane. In Friend, P.F. \& Williams, B.P.J. (eds) New Perspectives on the Old Red Sandstone. Geological Society of London, Special Publication. 180, 459-472.

BLUCK, B J. 1978. Sedimentation in a late orogenic basin: the Old Red Sandstone of the Midland Valley of Scotland. In BOWES, D R, and LEAKE, BE (eds) Crustal evolution in northwestern Britain and adjacent regions. Special Issue of the Geological Journal. 10, 249-278.

BLUCK, B.J. 1983. Role of the Midland Valley of Scotland in the Caledonian orogeny. Transactions of the Royal Society, Edinburgh: Earth Sciences. 74, 119-136.

BLUCK, B.J. 1984. Pre-Carboniferous history of the Midland Valley of Scotland. Transactions of the Royal Society, Edinburgh: Earth Sciences. 75, 275-296. 
BLUCK, B.J. 2000. Old Red Sandstone basins and alluvial systems of Midland Scotland. In FrIEND, P.F. \& Williams, B.P.J. (eds) New Perspectives on the Old Red Sandstone. Geological Society of London, Special Publication. 180, 417-437.

Browne, M.A.E., Sмith, R.A. \& AitKen, A.M. 2001. A lithostratigraphical framework for the Devonian (Old Red Sandstone) rocks of Scotland south of a line from Fort William to Aberdeen. British Geological Survey, Research Report. RR/01/04.

BuLL, E. 1995. Palaeontology and sedimentology of the North Esk inlier, Pentland Hills, near Edinburgh, Scotland. Open University, unpublished PhD thesis.

CAMERon, I. B. 1997. Geology of the Howgate Mouth area: Explanation of 1:10,000 Sheet NS93SW. British Geological Survey, Technical Report. WA/97/67.

Cameron, I.B. \& Stephenson, D. 1985. British Regional Geology: The Midland Valley of Scotland (third edition). British Geological Survey, HMSO.

Cocks, L.R.M. \& ToghiLL, P. 1973. The biostratigraphy of the Silurian rocks of the Girvan district, Scotland. Journal of the Geological Society, London. 129, 209-43.

Daly, J. S. 1996. Pre-Carboniferous history of the Annagh Gneiss Complex, North-western Ireland, and correlation with Laurentia-Baltica. Irish Journal of Earth Sciences. 74, 5-18.

Davis, A., McAdam, A.D. \& Cameron, I.B. 1986. Geology of the Dunbar district. Memoir of the British Geological Survey, Sheets 33E and part of 41 (Scotland).

DEAN, M. 2000. Preliminary report on the conodont biostratigraphy of a limestone 'pebble' in a conglomerate at Croy Foreshore, Ayrshire. British Geological Survey Technical Report. WH/00/10R.

Dickinson, W.R. \& SuCZEK, C.A. 1979. Plate tectonics and sandstone compositions. American Association of Petroleum Geologists Bulletin. 63, 2164-2182.

ELDERS, C. F. 1987. The provenance of granite boulders in conglomerates of the Northern and Central Belts of the southern Uplands of Scotland. Journal of the Geological Society of London. 144, 853-863.

Evans, J.A., Stone, P. \& Floyd, J.D. 1991. Isotopic characteristics of Ordovician greywacke provenance in the Southern Uplands of Scotland. In MorTon, A.C., TODD, S.P. \& HAughton, P.D.W. (eds) Developments in Sedimentary Provenance Studies. Geological Society of London, Special Publication. 57, 161-172. 
Haughton, P.D.W. 1988. A cryptic Caledonian flysch terrane in Scotland. Journal of the Geological Society, London. 145, 685-703.

Haughton, P.D.W. \& Bluck, B.J. 1989. Diverse alluvial sequences from the Lower Old Red Sandstone of the Strathmore region, Scotland - implications for the relationship between late Caledonian tectonics and sedimentation. Proceedings of the 2nd international symposium on the Devonian system. Canadian Society of Petroleum Geologists, Memoir. 14, 269-93.

Haughton, P.D.W., Rogers, G. \& Halliday, A.N. 1990. Provenance of Lower Old Red Sandstone conglomerates, SE Kincardineshire: evidence for the timing of Caledonian terrane accretion in central Scotland. Journal of the Geological Society, London. 147, 105-120.

Haughton, P.D.W. \& Halliday, A.N. 1991. Significance of late Caledonian igneous complex revealed by clasts in the Lower Old Red Sandstone conglomerates, central Scotland. Geological Society of America Bulletin. 103, 1476-92.

HeInZ, W. \& LoeschKe, J. 1988. Volcanic clasts in Silurian conglomerates of the Midland Valley (Hagshaw Hills inlier) Scotland, and their meaning for Caledonian plate tectonics. Geologische Rundschau. 77/2, 453-66.

Hutton, D. H. W., Aftalion, M. \& Halliday, A. N. 1985. An Ordovician ophiolite in County Tyrone, Ireland. Nature. 315, 210-212.

Hutchison, A.R. \& Oliver, G.J.H. 1998. Garnet provenance studies, juxtaposition of Laurentian marginal terranes and timing of the Grampian Orogeny in Scotland. Journal of the Geological Society of London. 155, 541-550.

Ingham, J K, CuRry, G B \& Williams, A. 1985. Early Ordovician Dounans Limestone fauna, Highland Border Complex, Scotland. Transactions of the Royal Society of Edinburgh: Earth Sciences. 76, 481-513.

Longman, C.D. Bluck, B.J., van Breeman, O. \& Aftalion, M. 1982. Ordovician conglomerates: constraints on the timescale. In OdIN, G.S. (ed) Numerical dating in stratigraphy. New York; Wiley, 807-9.

McAdam, A.D. \& Tulloch, W. 1985. Geology of the Haddington district. Memoir of the British Geological Survey, Sheets 33W and part of 41 (Scotland). 
McGiven, A. 1967. Sedimentation and provenance of post-Valentian conglomerates up to and including the basal conglomerate of the Lower Old Red Sandstone in the southern part of the Midland Valley of Scotland. University of Glasgow PhD. Thesis, unpublished.

McKerrow, W S , Dewey, J F \& Scotese, C F. 1991. The Ordovician and Silurian development of the Iapetus Ocean. In BASSETT, M G, LANE, P \& EdWARDS, D. (eds) The Murchison Symposium. Special Papers in Palaeontology. 44, 165-178.

MolyneuX, S G. 1992. A palynological report on samples from the Silurian of the Lesmahagow and Hagshaw Hills inliers (Scottish 1: 50000 Sheet 23). British Geological Survey, Technical Report WH/92/237.

MolyneuX, S.G. 1996. Palynology of samples from the Silurian North Esk, Loganlee and Bavelaw Castle inliers, Pentland Hills. British Geological Survey, Technical Report. WH/96/147R.

O’ConNoR, P.D. \& WiLliams D.M. 1988. Tectonic control on sedimentation during transgression: a case study from Silurian in Ireland and Scotland. Geological Magazine. 136, 75-82.

Paterson, I.B. McAdam, A.D. \& MacPherson, K.A.T. 1998. The geology of the country around Hamilton. Memoir of the British Geological Survey.

PEACH, B.N. \& HoRne, J. 1899. The Silurian rocks of Britain: Volume 1, Scotland. Memoir of the Geological Survey, UK.

PHILLIPS, E.R. 1994. Whole-rock geochemistry of the calc-alkaline Old Red Sandstone lavas, Sheet 15 (New Cumnock), Scotland. British Geological Survey, Technical Report. WG/94/1.

Phillips, E.R., Smith, R.A. \& CARRoll, S. 1998. Strike-slip, terrane accretion and the preCarboniferous evolution of the Midland Valley of Scotland. Transactions of the Royal Society or Edinburgh: Earth Sciences. 89, 209-224.

Phillips, E.R., Evans, J.A., Stone, P., Horstwood, M.S.A., Floyd, J.D., Smith, R.A., AKHuRst, M.C. \& BARRON, H.F. 2003. Detrital Avalonian zircons in the Laurentian Southern Uplands terrane, Scotland. Geology. 31, 625-628.

Robertson, G. 1989. A palaeoenvironmental interpretation of the Silurian rocks of the Pentland Hills, near Edinburgh. Transactions of the Royal Society or Edinburgh: Earth Sciences. 80, 127-41.

RoLfE, W.D.I. 1960. The Silurian inlier of Carmichael, Lanarkshire. Transactions of the Royal Society or Edinburgh: Earth Sciences. 64, 240-69. 
ROLFE, W.D.I. 1961. The geology of the Hagshaw Hills Silurian inlier, Lanarkshire. Transactions of the Edinburgh Geological Society. 18, 240-69.

RoLfE, W.D.I. \& Fritz, M.A. 1966. Recent evidence for the age of the Hagshaw Hills inlier, Lanarkshire. Scottish Journal of Geology. 18, 240-69.

SмITH, R A. 1993. Explanation for 1: 10000 Sheet NS72SE (Auchendaff). British Geological Survey, Technical Report. WA/93/34.

SмITH, R.A. 1995. The Siluro-Devonian evolution of the southern Midland Valley of Scotland. Geological Magazine. 132, 503-13.

SmITH, R.A. 2000. Geology of the Croy area. Explanation of 1:10 000 Sheet 21SE/SW. Part of 1:50 000 Sheet 14 (Ayr). British Geological Survey, Technical Report. WA/00/13.

Smith, R.A., Phillips, E.R., Floyd, J.D., BARRon, H.F. \& Pickett, E.A. 2001. The Northern Belt 100 years on: a revised model of the Ordovician tracts near Leadhills, Scotland. Transactions of the Edinburgh Geological Society. 91, 421-434.

SYBA, E. 1989. The sedimentation and provenance of the Lower Old Red Sandstone Greywacke Conglomerate, southern Midland Valley, Scotland. University of Glasgow PhD Thesis, unpublished.

ThIRLWALL, M.F. 1981. Implications for Caledonian plate tectonic models of chemical data from volcanic rocks of the British Old Red Sandstone. Journal of the Geological Society of London. 138, 123-38.

THIRLWALL, M.F. 1983. Isotope geochemistry and origin of calc-alkaline lavas from a Caledonian continental margin volcanic arc. Journal of Volcanology and Geothermal Research. 18, 589-631.

Wellman, C.H. \& Richardson, J.B. 1993. Terrestrial plant microfossils from Silurian inliers of the Midland Valley of Scotland. Palaeontology. 36, 155-193.

Williams, D.M. \& HARPER, D.A.T. 1988. A basin model for the Silurian of the Midland Valley of Scotland and Ireland. Journal of the Geological Society, London. 145, 741-748.

\section{Figures}

Fig. 1. Simplified geological map of the Midland Valley of Scotland showing the distribution of Silurian inliers and the Siluro-Devonian Lanark Group. 
Fig.2. Generalised vertical sections through the Silurian inliers and Siluro-Devonian sedimentary sequences and contemporaneous volcanic rocks of the New Cumnock, Lanark and Pentland Hills districts.

Fig. 3. Photomicrographs: (a) coarse-grained, very closely packed sandstone, Eastgate Formation (Carmichael inlier); (b) coarse-grained sandstone rich in clasts of fine- to very fine-grained volcanic rocks, Cock Rig Formation (North Esk inlier); (c) very coarse-grained, pebbly sandstone or microconglomerate containing small pebbles of porphyritic basaltic to andesitic rock, Cock Rig Formation (North Esk inlier); (d) medium-grained sandstone, Swanshaw Sandstone Formation (Lanark Group); and (e) very coarse-grained sandstone containing haematised volcanic rock fragments, Auchtitench Sandstone Formation (Lanark Group). All photographs taken under plane polarised light; scale bar $=1.0 \mathrm{~mm}$.

Fig. 4. Bivariant plots showing the variation in: (a) polycrystalline quartz; (b) volcanic lithic clasts; (c) plagioclase; and (d) metamorphic lithic clasts with respect to monocrystalline quartz. Compositional trends shown by arrows (see text for details).

Fig. 5. Log-ratio plots showing the variation in: (a) $\log (\operatorname{Lv} / \mathrm{Lt})$ versus $\log (\mathrm{Qm} / \mathrm{Lt})$; (b) $\log (\operatorname{Lv} / \mathrm{Lt})$ versus $\log (\mathrm{Pl} / \mathrm{Lt})$; (c) $\log (\mathrm{Qm} / \mathrm{Lt}$ ) versus $\log (\mathrm{Lm} / \mathrm{Lt})$; and (d) $\log (\mathrm{Qp} / \mathrm{Lt})$ versus $\log (\mathrm{Qm} / \mathrm{Lt}$ ) (for key to symbols see Fig. 3). Compositional trends shown by arrows (see text for details).

Fig. 6. Ternary diagrams for determining sandstone provenance (after Dickinson \& Suczek 1979). (a) Quartz-Feldspar-Lithics. (b) Monocrystalline quartz-Feldspar-Total Lithics (for key to symbols see Fig. 3).

Fig. 7. Lithostratigraphical variation in mono- and polycrystalline quartz, plagioclase, metamorphic and volcanic lithic contents of sandstones from the Silurian inliers and Lanark Group of: (a) Pentland Hills (North Esk inlier); (b) Lanark district to the northwest of the Carmichael Fault; (c) Lanark district to the southeast of the Carmichael Fault; and (d) New Cumnock district (Lanark Group only).

\section{Tables}

Table 1. Major and minor detrital components within the main lithostratigraphical units of the Silurian Carmichael, Eastfield and North Esk inliers, and Siluro-Devonian Lanark Group.

Table 2. Representative sandstone compositional data for Silurian and Lanark Group sequences exposed in the southern Midland Valley. 


\begin{tabular}{|c|c|c|c|c|}
\hline $\begin{array}{l}\text { Lithostratigraphical } \\
\text { unit }\end{array}$ & Lithology & Major components & Minor components & $\begin{array}{l}\text { Trace to accessory } \\
\text { components }\end{array}$ \\
\hline $\begin{array}{l}\text { March Wood } \\
\text { Formation }\end{array}$ & litharenite & $\begin{array}{l}\text { basaltic to andesitic volcanic rock } \\
\text { fragments with subordinate } \\
\text { monocrystalline quartz }\end{array}$ & $\begin{array}{l}\text { polycrystalline quartz, biotite- } \\
\text { microporphyritic dacite, mica-rich } \\
\text { phyllitic/schistose rock (locally graphitic or } \\
\text { oxide-rich), psammite, variably haematised } \\
\text { basalt, very low-grade (sub-greenschist facies) } \\
\text { metasiltstones or mudstone, granite, meta- } \\
\text { quartz arenite, biotite schistose rock, felsite, } \\
\text { very fine-grained sandstone, mudstone }\end{array}$ & $\begin{array}{l}\text { muscovite, biotite, garnet, } \\
\text { oxidised biotite, perthite, } \\
\text { micrographic intergrowth, } \\
\text { chlorite, tourmaline, epidote, } \\
\text { K-feldspar (including } \\
\text { microcline) }\end{array}$ \\
\hline Eastgate Formation & litharenite & $\begin{array}{l}\text { volcanic rock fragments, } \\
\text { monocrystalline quartz, subordinate } \\
\text { feldspar (mainly plagioclase) }\end{array}$ & $\begin{array}{l}\text { quartz-chlorite schistose rock, hematised } \\
\text { mudstone or tuff, mica-rich phyllite, very } \\
\text { fine-grained sandstone, felsite, amphibole- } \\
\text { phyric andesite, quartzite, very fine-grained } \\
\text { psammite, quartzose mylonite, metabasalt, } \\
\text { trachyte, mylonitic metabasalt, fine-grained } \\
\text { 'wacke' sandstone or metasandstone, } \\
\text { mudstone, siltstone, chert }\end{array}$ & $\begin{array}{l}\text { Polycrystalline quartz, opaque } \\
\text { minerals, muscovite, } \\
\text { micrographic intergrowth, } \\
\text { variably altered biotite, } \\
\text { perthite, epidote, K-feldspar, } \\
\text { tourmaline, garnet, zircon, } \\
\text { chlorite pseudomorphs after } \\
\text { ferromagnesian minerals }\end{array}$ \\
\hline \multirow[t]{2}{*}{$\begin{array}{l}\text { Kirk Hill } \\
\text { Conglomerate } \\
\text { Member }\end{array}$} & $\begin{array}{l}\text { conglomerate to } \\
\text { microconglomerate } \\
\text { (granule to pebble } \\
\text { sized clasts) }\end{array}$ & $\begin{array}{l}\text { igneous rock fragments including: } \\
\text { chloritised basalt/basaltic andesite, } \\
\text { feldspar-quartz-phyric dacite, } \\
\text { plagioclase-phyric andesite, feldspar- } \\
\text { quartz-biotite-phyric rhyolite, } \\
\text { cryptocrystalline acidic volcanic rock, } \\
\text { biotite-granite to granodiorite, tonalite, } \\
\text { lapilli tuff, trachyte }\end{array}$ & quartzite, feldspathic sandstone & \\
\hline & sandstone matrix & $\begin{array}{l}\text { basaltic volcanic rock fragments, } \\
\text { monocrystalline quartz }\end{array}$ & $\begin{array}{l}\text { basalt, very fine-grained sandstone, chert, } \\
\text { cryptocrystalline quartz, mica-rich phyllite or } \\
\text { schist }\end{array}$ & $\begin{array}{l}\text { polycrystalline quartz, garnet, } \\
\text { plagioclase, chlorite, } \\
\text { muscovite, opaque minerals }\end{array}$ \\
\hline $\begin{array}{l}\text { Cock Rig } \\
\text { Formation }\end{array}$ & $\begin{array}{l}\text { conglomerate to } \\
\text { microconglomerate } \\
\text { (granule to pebble } \\
\text { sized clasts) }\end{array}$ & $\begin{array}{l}\text { dacite \& rhyolite volcanic rock } \\
\text { fragments }\end{array}$ & $\begin{array}{l}\text { trachyte, microgranite/tonalite with a well } \\
\text { developed micrographic intergrowth, low- } \\
\text { grade metasandstone, andesite, microdiorite, } \\
\text { dacitic tuff, quartzite, quartz-feldspar-phyric } \\
\text { rhyolite (porphyry), feldspathic } \\
\text { metasandstone, meta-quartz arenite } \\
\end{array}$ & $\begin{array}{l}\text { andesite, jaspery chert, } \\
\text { feldspathic quartzite, vein } \\
\text { quartz, haematised sandstone, } \\
\text { rare oolitic limestone }\end{array}$ \\
\hline
\end{tabular}




\begin{tabular}{|c|c|c|c|c|}
\hline & sandstone matrix & $\begin{array}{l}\text { mono- \& polycrystalline quartz, } \\
\text { andesitic/felsitic volcanic rock } \\
\text { fragments }\end{array}$ & & $\begin{array}{l}\text { chloritised biotite, plagioclase, } \\
\text { garnet, chlorite, ooids, crinoid } \\
\text { fragments, shell fragments, } \\
\text { muscovite, micrographic } \\
\text { intergrowth, opaque minerals, } \\
\text { K-feldspar, zircon, } \\
\text { chalcedonic quartz, chert }\end{array}$ \\
\hline $\begin{array}{l}\text { Henshaw } \\
\text { Formation: Igneous } \\
\text { Conglomerate }\end{array}$ & $\begin{array}{l}\text { conglomerate to } \\
\text { microconglomerate }\end{array}$ & $\begin{array}{l}\text { andesitic, dacitic to possibly rhyolitic } \\
\text { volcanic rock fragments, subordinate } \\
\text { mono- \& polycrystalline quartz }\end{array}$ & $\begin{array}{l}\text { hyalopilitic rhyolite, quartz-feldspar-biotite- } \\
\text { phyric dacite (porphyry), chloritised } \\
\text { amygdaloidal andesite or basalt, haematised } \\
\text { volcanic rock, haematised lapilli-tuff, } \\
\text { microgranite, ignimbrite, pilotaxitic trachyte, } \\
\text { tonalite or quartz diorite, granite, very fine- } \\
\text { grained sandstone, coarse siltstone, } \\
\text { volcaniclastic sandstone, feldspathic } \\
\text { sandstone, fine-grained sandstone and coarse } \\
\text { siltstone with a chloritic matrix }\end{array}$ & $\begin{array}{l}\text { meta-quartz arenite, mica-rich } \\
\text { phyllitic or schistose rock, } \\
\text { plagioclase, micrographic } \\
\text { intergrowth, opaque minerals, } \\
\text { tourmaline, perthite, K- } \\
\text { feldspar, biotite, muscovite, } \\
\text { epidote, quartz-chlorite vein } \\
\text { material, rare very fine- } \\
\text { grained biotite hornfels }\end{array}$ \\
\hline \multirow[t]{2}{*}{$\begin{array}{l}\text { Henshaw } \\
\text { Formation: } \\
\text { Quartzite } \\
\text { Conglomerate }\end{array}$} & $\begin{array}{l}\text { conglomerate to } \\
\text { microconglomerate }\end{array}$ & $\begin{array}{l}\text { dacite to rhyolite volcanic rock } \\
\text { fragments, polycrystalline quartz, } \\
\text { quartzite, monocrystalline quartz }\end{array}$ & $\begin{array}{l}\text { haematised andesite, weakly amygdaloidal } \\
\text { andesite, feldspar microporphyritic dacite, } \\
\text { sheared/mylonitised polycrystalline quartz, } \\
\text { carbonate-haematite rock, cleaved mudstone } \\
\text { or tuff, altered microgranite or quartz diorite, } \\
\text { fine-grained psammite, haematitic siltstone, } \\
\text { fine-grained feldspathic sandstone, laminated } \\
\text { mudstone, altered volcaniclastic sandstone }\end{array}$ & \\
\hline & sandstone matrix & mono- \& polycrystalline quartz & felsic volcanic rock fragments & $\begin{array}{l}\text { muscovite, tourmaline, } \\
\text { epidote, sericitised feldspar, } \\
\text { cleaved chloritic mudstone, } \\
\text { psammite, micaceous phyllite }\end{array}$ \\
\hline $\begin{array}{l}\text { Greywacke } \\
\text { Conglomerate } \\
\text { Formation }\end{array}$ & litharenite & $\begin{array}{l}\text { andesitic to dacitic rock fragments, } \\
\text { monocrystalline quartz, plagioclase }\end{array}$ & $\begin{array}{l}\text { felsite, very fine-grained sandstone, white } \\
\text { mica-chlorite phyllite, fine-grained psammite, } \\
\text { quartz-chlorite schist, cleaved mudstone, } \\
\text { siltstone, crenulated phyllite, quartzite, } \\
\text { chloritised basalt, granite }\end{array}$ & $\begin{array}{l}\text { polycrystalline quartz, } \\
\text { muscovite, biotite, } \\
\text { polycrystalline epidote, } \\
\text { chlorite, micrographic } \\
\text { intergrowth, K-feldspar, } \\
\text { microcline, white }\end{array}$ \\
\hline
\end{tabular}




\begin{tabular}{|c|c|c|c|c|}
\hline & & & & $\begin{array}{l}\text { mica/muscovite, garnet, } \\
\text { tourmaline, zircon, chlorite } \\
\text { pseudomorphs after } \\
\text { ferromagnesian minerals }\end{array}$ \\
\hline $\begin{array}{l}\text { Greywacke } \\
\text { Conglomerate } \\
\text { Formation }\end{array}$ & conglomerate & $\begin{array}{l}\text { fine-grained wacke sandstone, } \\
\text { litharenite, coarse siltstone }\end{array}$ & $\begin{array}{l}\text { chloritised basalt, mudstone, chert, fine } \\
\text { siltstone, devitrified glass or tuffaceous rock, } \\
\text { cleaved siltstone or mudstone, jasper, } \\
\text { cataclasite, polycrystalline vein quartz, } \\
\text { quartzite, meta-quartz arenite, tourmaline- } \\
\text { bearing granite, two mica granite, feldspar- } \\
\text { biotite-quartz-phyric rhyolite, feldspathic } \\
\text { metasandstone, quartzose sandstone, fine- } \\
\text { grained carbonate rock, felsite }\end{array}$ & $\begin{array}{l}\text { biotite, polycrystalline quartz, } \\
\text { opaque minerals }\end{array}$ \\
\hline $\begin{array}{l}\text { Swanshaw } \\
\text { Sandstone } \\
\text { Formation }\end{array}$ & litharenite & $\begin{array}{l}\text { altered volcanic lithic clasts, } \\
\text { monocrystalline quartz, plagioclase }\end{array}$ & $\begin{array}{l}\text { very fine-grained schist, pilotaxitic trachyte, } \\
\text { quartz-microporphyritic rhyolite, } \\
\text { chert/cryptocrystalline quartz, dacite, altered } \\
\text { variolitic basalt, amphibole-phyric andesite, } \\
\text { chloritised basalt/metabasalt, fine-grained } \\
\text { sandstone, siltstone, psammite, quartzite, fine- } \\
\text { grained hornfels }\end{array}$ & $\begin{array}{l}\text { polycrystalline quartz, biotite, } \\
\text { muscovite, K-feldspar, } \\
\text { perthite, microcline, chlorite, } \\
\text { carbonate, carbonate rock, } \\
\text { tourmaline, amphibole, } \\
\text { opaque minerals, apatite, } \\
\text { deformed vein quartz or } \\
\text { quartz mylonite, chlorite } \\
\text { pseudomorphs after } \\
\text { ferromagnesian minerals }\end{array}$ \\
\hline
\end{tabular}




\begin{tabular}{|c|c|c|c|c|}
\hline & quartzose litharenite & $\begin{array}{l}\text { monocrystalline quartz, variably } \\
\text { degraded volcanic rock fragments }\end{array}$ & $\begin{array}{l}\text { rhyolite, felsite, mudstone, haematised } \\
\text { metabasalt, chert, quartzite, cleaved } \\
\text { mudstone, biotite-schist, white mica-rich } \\
\text { phyllite or schist, trachytic rock, chloritic } \\
\text { sandstone and siltstone, phyllite/slate, very } \\
\text { fine-grained microgranite/rhyolite, haematised } \\
\text { mudstone \& siltstone }\end{array}$ & $\begin{array}{l}\text { polycrystalline quartz, } \\
\text { plagioclase, sericitised rock or } \\
\text { feldspar, opaque minerals, } \\
\text { tourmaline, titanite/rutile, } \\
\text { white mica, garnet, biotite, K- } \\
\text { feldspar, chloritic } \\
\text { pseudomorphs after } \\
\text { ferromagnesian minerals, } \\
\text { staurolite }\end{array}$ \\
\hline $\begin{array}{l}\text { Biggar Volcanic } \\
\text { Formation }\end{array}$ & litharenite & $\begin{array}{l}\text { andesitic volcanic rock fragments, } \\
\text { including: plagioclase-phyric basaltic } \\
\text { andesite, plagioclase-amphibole-phyric } \\
\text { andesite, aphyric andesite and dacite, } \\
\text { feldspar-biotite-phyric dacite, } \\
\text { amygdaloidal pilotaxitic andesite } \\
\end{array}$ & plagioclase & $\begin{array}{l}\text { monocrystalline quartz, } \\
\text { devitrified glass, opaque } \\
\text { minerals, altered feldspar, } \\
\text { zircon, muscovite, mudstone, } \\
\text { fine siltstone }\end{array}$ \\
\hline \multirow[t]{2}{*}{$\begin{array}{l}\text { Auchtitench } \\
\text { Sandstone } \\
\text { Formation }\end{array}$} & $\begin{array}{l}\text { lithic-rich to } \\
\text { feldspathic } \\
\text { sandstone }\end{array}$ & $\begin{array}{l}\text { monocrystalline quartz, plagioclase, } \\
\text { andesitic to dacitic volcanic rock } \\
\text { fragments }\end{array}$ & & $\begin{array}{l}\text { microcline, polycrystalline } \\
\text { quartz, epidote, garnet, } \\
\text { perthite, felsite, opaque } \\
\text { minerals, tourmaline, chlorite, } \\
\text { rutile, white mica/muscovite, } \\
\text { amphibole, chlorite after } \\
\text { detrital ferromagnesian } \\
\text { minerals, quartz-chlorite rock } \\
\text { or vein material, rare } \\
\text { metasedimentary and quartzite } \\
\text { rock fragments }\end{array}$ \\
\hline & $\begin{array}{l}\text { volcaniclastic } \\
\text { sandstone }\end{array}$ & $\begin{array}{l}\text { basaltic andesitic to dacitic volcanic } \\
\text { rock fragments, including: plagioclase- } \\
\text { phyric basaltic andesite, plagioclase- } \\
\text { amphibole-phyric andesite, aphyric } \\
\text { andesite and dacite, feldspar-biotite- } \\
\text { phyric dacite, amygdaloidal pilotaxitic } \\
\text { andesite }\end{array}$ & plagioclase & $\begin{array}{l}\text { monocrystalline quartz, } \\
\text { devitrified glass, opaque } \\
\text { minerals, zircon, chloritised } \\
\text { biotite, muscovite, mudstone, } \\
\text { fine siltstone }\end{array}$ \\
\hline
\end{tabular}




\begin{tabular}{|c|c|c|c|c|c|c|c|c|c|c|c|c|c|c|c|}
\hline sample & $\begin{array}{l}\text { New Cum } \\
\text { group }\end{array}$ & $\begin{array}{l}\text { ock District } \\
\text { formation }\end{array}$ & $\begin{array}{c}\text { modal } \% \\
\mathrm{~N}\end{array}$ & Qm & Qp & Pl & Ksp & Ls & $\mathbf{L m}$ & $\mathbf{L v}$ & Lg & L total & Op & matrix & cement \\
\hline ETS 229 & Lanark & Swanshaw Sandstone Fm & 896 & 29 & 9 & 5 & 1 & 0 & 13 & 27 & 0 & 50 & 1 & 12 & 0 \\
\hline ETS 227 & Lanark & Swanshaw Sandstone Fm & 1002 & 17 & 3 & 6 & 0 & 5 & 17 & 16 & 0 & 41 & 1 & 33 & 0 \\
\hline ETS 166 & Lanark & Swanshaw Sandstone Fm & 911 & 34 & 6 & 5 & 0 & 4 & 16 & 12 & 0 & 38 & 1 & 22 & 0 \\
\hline ETS 225 & Lanark & Swanshaw Sandstone Fm & 902 & 33 & 4 & 9 & 1 & 0 & 7 & 18 & 0 & 29 & 5 & 20 & 0 \\
\hline ETS 23 & Lanark & Duneaton Volcanic Fm & 878 & 1 & 0 & 12 & 0 & 0 & 0 & 71 & 0 & 72 & 0 & 14 & 0 \\
\hline ETS 26 & Lanark & Duneaton Volcanic Fm & 835 & 1 & 0 & 2 & 0 & 0 & 0 & 87 & 0 & 87 & 0 & 10 & 0 \\
\hline ETS 170 & Lanark & Duneaton Volcanic Fm & 738 & 0 & 0 & 2 & 0 & 0 & 0 & 70 & 0 & 70 & 0 & 27 & 0 \\
\hline ETS 139 & Lanark & Duneaton Volcanic Fm & 736 & 0 & 0 & 1 & 0 & 0 & 0 & 88 & 0 & 88 & 0 & 10 & 0 \\
\hline ETS 101 & Lanark & Auchtitench Sandstone Fm & 962 & 2 & 1 & 9 & 1 & 0 & 3 & 68 & 0 & 72 & 0 & 15 & 0 \\
\hline ETS 90 & Lanark & Auchtitench Sandstone Fm & 977 & 0 & 1 & 13 & 0 & 0 & 0 & 66 & 0 & 68 & 1 & 19 & 0 \\
\hline ETS 112 & Lanark & Auchtitench Sandstone Fm & 929 & 14 & 2 & 9 & 1 & 0 & 1 & 54 & 0 & 58 & 1 & 16 & 0 \\
\hline ETS 132 & Lanark & Auchtitench Sandstone Fm & 1123 & 10 & 3 & 9 & 1 & 0 & 2 & 62 & 0 & 67 & 1 & 12 & 0 \\
\hline ETS 137 & Lanark & Auchtitench Sandstone Fm & 1038 & 1 & 0 & 1 & 0 & 0 & 0 & 90 & 0 & 90 & 0 & 8 & 0 \\
\hline ETS 209 & Lanark & Auchtitench Sandstone Fm & 1000 & 18 & 3 & 11 & 1 & 0 & 1 & 57 & 0 & 62 & 1 & 6 & 0 \\
\hline ETS 129 & Lanark & Auchtitench Sandstone Fm & 955 & 37 & 5 & 20 & 2 & 0 & 2 & 16 & 1 & 23 & 1 & 15 & 0 \\
\hline ETS 222 & Lanark & Auchtitench Sandstone Fm & 936 & 32 & 5 & 20 & 1 & 0 & 3 & 13 & 0 & 21 & 2 & 20 & 0 \\
\hline ETS 198 & Lanark & Auchtitench Sandstone Fm & 990 & 32 & 4 & 11 & 1 & 0 & 2 & 22 & 0 & 29 & 1 & 26 & 0 \\
\hline ETS 135 & Lanark & Auchtitench Sandstone Fm & 942 & 17 & 4 & 14 & 1 & 1 & 2 & 51 & 1 & 58 & 0 & 9 & 0 \\
\hline sample & $\begin{array}{l}\text { Pentland I } \\
\text { group }\end{array}$ & $\begin{array}{l}\text { ills: North Esk Inlier } \\
\text { formation }\end{array}$ & $\begin{array}{c}\text { modal \% } \\
\mathbf{N} \\
\end{array}$ & Qm & Qp & Pl & Ksp & Ls & $\mathbf{L m}$ & $\mathbf{L v}$ & Lg & L total & Op & matrix & cement \\
\hline N891 & Pentlands & Cock Rig Fm & 1005 & 15 & 9 & 4 & 0 & 3 & 16 & 39 & 4 & 72 & 0 & 7 & 0 \\
\hline N890 & Pentlands & Cock Rig Fm & 960 & 24 & 7 & 3 & 1 & 1 & 5 & 48 & 1 & 62 & 0 & 10 & 0 \\
\hline N889 & Pentlands & Cock Rig Fm & 949 & 21 & 14 & 0 & 0 & 4 & 15 & 36 & 1 & 71 & 0 & 7 & 0 \\
\hline S99025 & Pentlands & Cock Rig Fm & 919 & 40 & 9 & 7 & 1 & 0 & 3 & 29 & 0 & 41 & 1 & 9 & 0 \\
\hline N885 & Pentlands & Igneous Conglomerate & 989 & 4 & 4 & 1 & 1 & 21 & 5 & 54 & 5 & 89 & 0 & 5 & 0 \\
\hline N884 & Pentlands & Igneous Conglomerate & 978 & 6 & 5 & 3 & 1 & 9 & 12 & 55 & 2 & 82 & 0 & 8 & 0 \\
\hline N886 & Pentlands & Quartzite Conglomerate & 1123 & 7 & 44 & 11 & 0 & 2 & 8 & 18 & 0 & 72 & 0 & 9 & 0 \\
\hline S98800 & Pentlands & Henshaw Fm & 992 & 41 & 6 & 9 & 0 & 0 & 8 & 10 & 0 & 25 & 1 & 19 & 0 \\
\hline S98798 & Lanark & Greywacke Conglomerate Fm & 674 & 28 & 3 & 4 & 0 & 0 & 5 & 14 & 0 & 22 & 3 & 38 & 0 \\
\hline S98805 & Lanark & Greywacke Conglomerate Fm & 992 & 26 & 7 & 3 & 0 & 5 & 11 & 14 & 0 & 36 & 2 & 29 & 0 \\
\hline
\end{tabular}




\begin{tabular}{|c|c|c|c|c|c|c|c|c|c|c|c|c|c|c|c|}
\hline S99021 & Lanark & Greywacke Conglomerate Fm & 977 & 27 & 9 & 2 & 0 & 1 & 23 & 16 & 1 & 50 & 1 & 18 & 0 \\
\hline sample & $\begin{array}{l}\text { Lanark Dist } \\
\text { group }\end{array}$ & $\begin{array}{l}\text { trict: East Field Inlier } \\
\text { formation }\end{array}$ & $\begin{array}{c}\text { modal \% } \\
\mathrm{N}\end{array}$ & Qm & Qp & Pl & Ksp & Ls & Lm & $\mathbf{L v}$ & Lg & L total & Op & matrix & cement \\
\hline N1017 & Tinto & March Wood Formation & 880 & 32 & 5 & 12 & 1 & 0 & 8 & 25 & 0 & 38 & 0 & 10 & 0 \\
\hline N1015 & Tinto & March Wood Formation & 996 & 19 & 6 & 5 & 0 & 1 & 9 & 40 & 1 & 56 & 1 & 16 & 0 \\
\hline N1043 & Lanark & Greywacke Conglomerate Formation & 997 & 19 & 6 & 5 & 0 & 0 & 11 & 37 & 1 & 55 & 1 & 18 & 0 \\
\hline N1044 & Lanark & Greywacke Conglomerate Formation & 987 & 19 & 7 & 6 & 0 & 0 & 13 & 35 & 2 & 58 & 1 & 13 & 0 \\
\hline N1032 & Lanark & Auchtitench Sandstone Formation & 985 & 1 & 0 & 8 & 0 & 0 & 0 & 70 & 0 & 70 & 1 & 20 & 0 \\
\hline N1028 & Lanark & Auchtitench Sandstone Formation & 985 & 0 & 0 & 3 & 0 & 0 & 0 & 89 & 0 & 89 & 0 & 6 & 0 \\
\hline N1026 & Lanark & Auchtitench Sandstone Formation & 1004 & 0 & 0 & 2 & 0 & 4 & 0 & 80 & 0 & 84 & 1 & 13 & 0 \\
\hline S99333 & Lanark & Auchtitench Sandstone Formation & 998 & 42 & 6 & 9 & 1 & 0 & 2 & 13 & 0 & 22 & 0 & 24 & 0 \\
\hline S99335 & Lanark & Auchtitench Sandstone Formation & 991 & 40 & 4 & 20 & 1 & 0 & 3 & 10 & 0 & 17 & 1 & 20 & 0 \\
\hline sample & $\begin{array}{l}\text { Lanark Dist } \\
\text { group }\end{array}$ & $\begin{array}{l}\text { trict: Carmichael Inlier } \\
\text { formation }\end{array}$ & $\begin{array}{c}\text { modal \% } \\
\mathbf{N}\end{array}$ & Qm & Qp & Pl & Ksp & Ls & Lm & $\mathbf{L v}$ & Lg & L total & Op & matrix & cement \\
\hline N1049 & Carmichael & Eastgate Formation & 996 & 37 & 5 & 14 & 0 & 1 & 6 & 18 & 1 & 31 & 0 & 13 & 0 \\
\hline N1048 & Carmichael & Eastgate Formation & 985 & 28 & 5 & 12 & 0 & 0 & 10 & 26 & 2 & 43 & 1 & 13 & 0 \\
\hline N1050 & Carmichael & Eastgate Formation & 1000 & 21 & 6 & 16 & 1 & 0 & 12 & 28 & 1 & 47 & 1 & 12 & 0 \\
\hline S79232 & Carmichael & Eastgate Formation & 984 & 23 & 7 & 14 & 1 & 0 & 8 & 27 & 1 & 44 & 1 & 15 & 0 \\
\hline N1055 & Lanark & Greywacke Conglomerate Formation & 993 & 28 & 6 & 13 & 1 & 0 & 8 & 31 & 0 & 45 & 1 & 8 & 0 \\
\hline N1052 & Lanark & Swanshaw Sandstone Formation & 952 & 31 & 6 & 12 & 0 & 0 & 10 & 25 & 1 & 43 & 1 & 9 & 0 \\
\hline N1054 & Lanark & Swanshaw Sandstone Formation & 983 & 26 & 5 & 13 & 1 & 2 & 8 & 22 & 1 & 38 & 1 & 18 & 0 \\
\hline N2140 & Lanark & Swanshaw Sandstone Formation & 1002 & 42 & 23 & 3 & 1 & 1 & 6 & 6 & 0 & 36 & 0 & 18 & 0 \\
\hline N2134 & Lanark & Swanshaw Sandstone Formation & 1009 & 45 & 13 & 7 & 0 & 0 & 3 & 5 & 0 & 21 & 1 & 12 & 13 \\
\hline N2133 & Lanark & Swanshaw Sandstone Formation & 1056 & 30 & 7 & 9 & 1 & 1 & 5 & 9 & 0 & 22 & 3 & 24 & 6 \\
\hline N2131 & Lanark & Swanshaw Sandstone Formation & 1034 & 30 & 8 & 14 & 1 & 1 & 9 & 11 & 0 & 28 & 2 & 22 & 0 \\
\hline sample & $\begin{array}{l}\text { Hamilton D } \\
\text { group }\end{array}$ & $\begin{array}{l}\text { istrict } \\
\text { formation }\end{array}$ & $\begin{array}{c}\text { modal \% } \\
\mathrm{N}\end{array}$ & Qm & Qp & Pl & Ksp & Ls & Lm & $\mathbf{L v}$ & Lg & L total & Op & matrix & cement \\
\hline S33752 & Lanark & Swanshaw Sandstone Formation & 978 & 23 & 6 & 8 & 0 & 3 & 5 & 28 & 0 & 43 & 1 & 23 & 0 \\
\hline S53608 & Lanark & Swanshaw Sandstone Formation & 1000 & 1 & 0 & 3 & 0 & 7 & 0 & 67 & 0 & 74 & 0 & 22 & 0 \\
\hline sample & $\begin{array}{l}\text { Ayr District } \\
\text { group }\end{array}$ & formation & $\begin{array}{c}\text { modal \% } \\
\mathbf{N} \\
\end{array}$ & Qm & Qp & Pl & Ksp & Ls & $\mathbf{L m}$ & $\mathbf{L v}$ & Lg & L total & Op & matrix & cement \\
\hline S33752 & Lanark & Swanshaw Sandstone Formation & 1038 & 30 & 11 & 6 & 2 & 4 & 14 & 16 & 1 & 46 & 2 & 9 & 0 \\
\hline
\end{tabular}




\begin{tabular}{|c|c|c|c|c|c|c|c|c|c|c|c|c|c|c|c|}
\hline N2215 & Lanark & Swanshaw Sandstone Formation & 1031 & 29 & 8 & 7 & 2 & 1 & 6 & 9 & 0 & 25 & 2 & 16 & 16 \\
\hline N2216 & Lanark & Swanshaw Sandstone Formation & 1018 & 21 & 7 & 5 & 2 & 1 & 8 & 12 & 0 & 29 & 0 & 0 & 40 \\
\hline N2207 & Lanark & Swanshaw Sandstone Formation & 1029 & 19 & 8 & 6 & 1 & 1 & 8 & 23 & 0 & 40 & 0 & 3 & 27 \\
\hline
\end{tabular}

Table 2. Representative sandstone compositional data obtained for the Silurian and Lanark Group sequences exposed in the southern Midland Valley. 


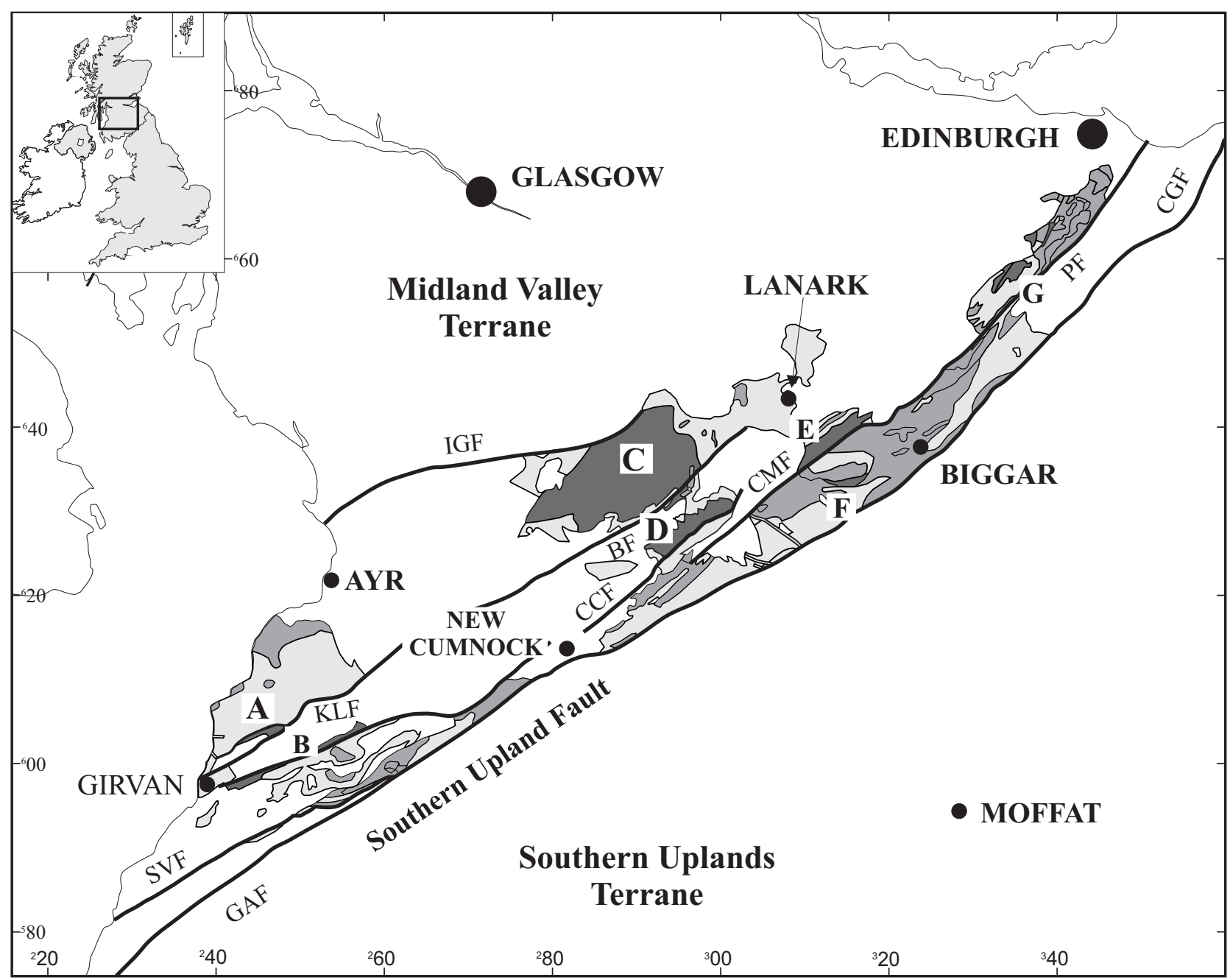

Midland Valley Silurian inliers Lanark Group sedimentary rocks Lanark Group igneous rocks

Silurian inliers: A, Craighead; B, Girvan Main; C, Lesmahagow; D, Hagshaw Hills; E, Carmichael; F, Eastfield; G, Pentland Hills (North Esk).

Faults: SVF, Stinchar Valley Fault; GAF, Glen App Fault; KLF, Kerse Loch Fault; BF, Bankend Fault; CCF, Carmacoup Fault; IGF, Inchgotrick Fault, CMF, Carmichael Fault; PF, Pentland Fault; CGF, Crossgatehall Fault. 


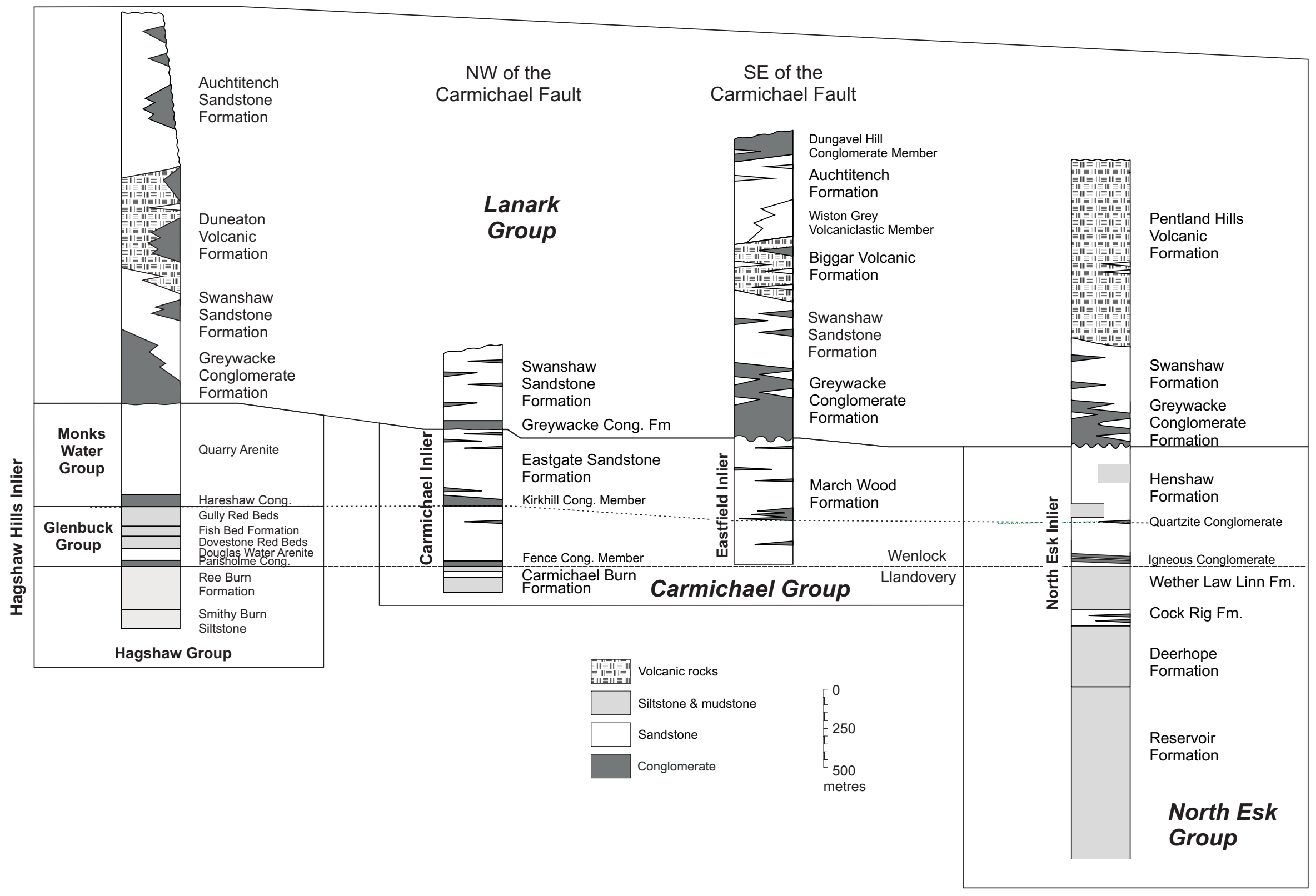




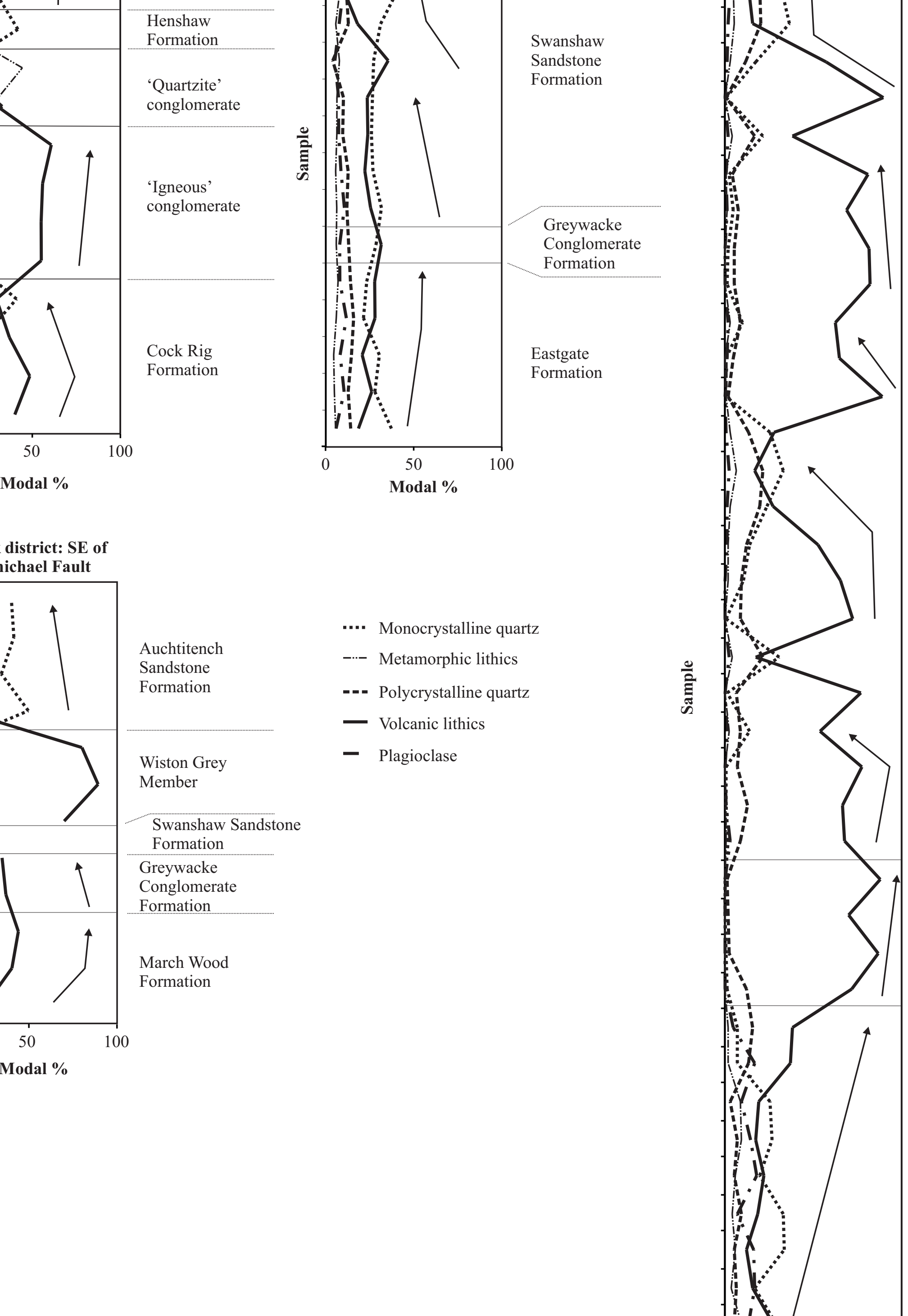



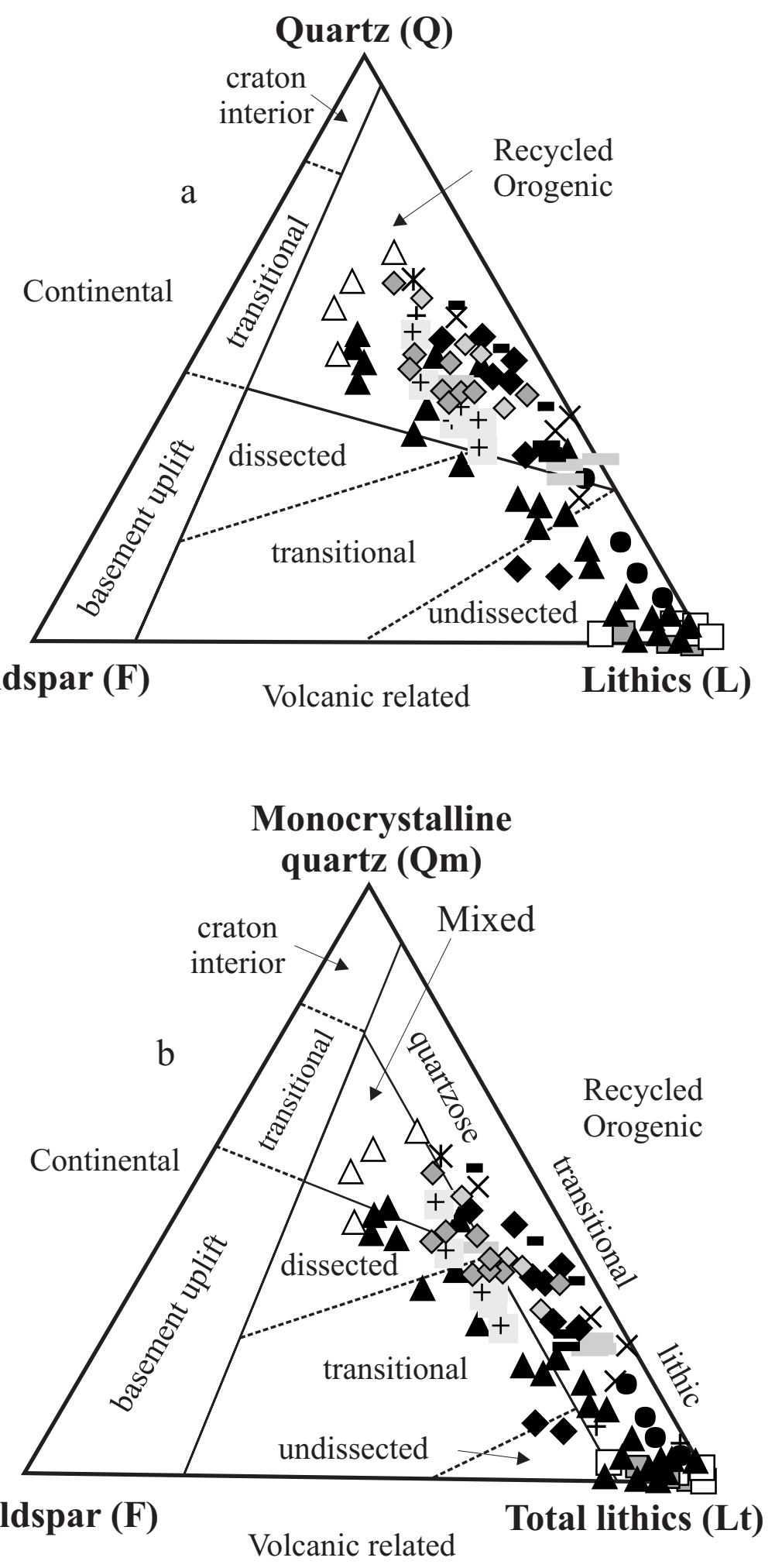

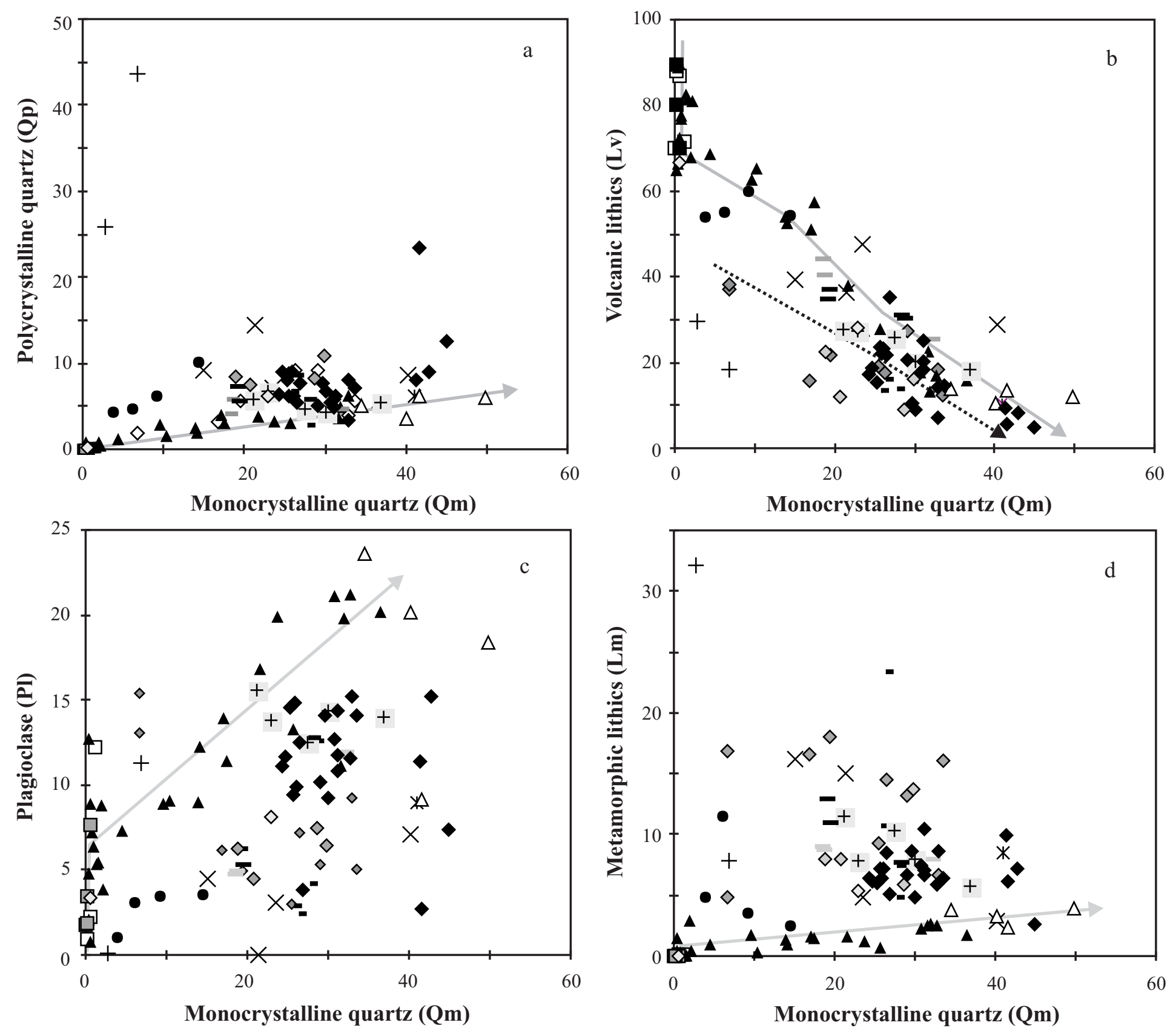

Pentland Hills North Esk inlier $\times$ Cock Rig Fm

* Henshaw Fm

- Igneous Conglomerate

+ Quartzite Conglomerate

- Greywacke Conglomerate Fm

Ayr district

$\diamond$ Swanshaw Sandstone Fm
Lanark district Eastfield inlier

$\square$ March Wood Fm

- Greywacke Conglomerate Fm

$\square$ Wiston Grey Volcaniclastic Mbr

$\triangle$ Auchtitench Sandstone Fm

Hamilton district

$\diamond$ Swanshaw Sandstone Fm
Lanark district Carmichael inlier

+ Eastgate Fm

- Greywacke Conglomerate Fm Swanshaw Sandstone Fm

\section{New Cumnock district}

$\diamond \quad$ Swanshaw Sandstone Fm

Duneaton Volcanic Fm

A Auchtitench Sandstone Fm 
$\log (\operatorname{Lv} / \mathbf{L t})$

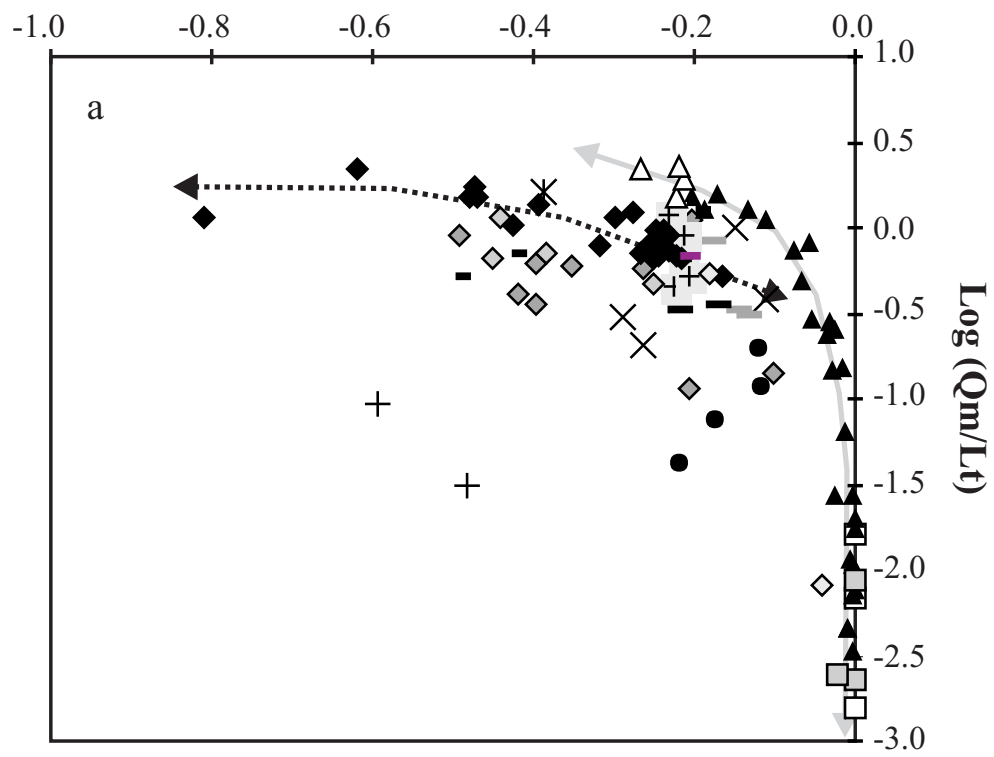

$\log (\mathbf{Q m} / \mathbf{L t})$

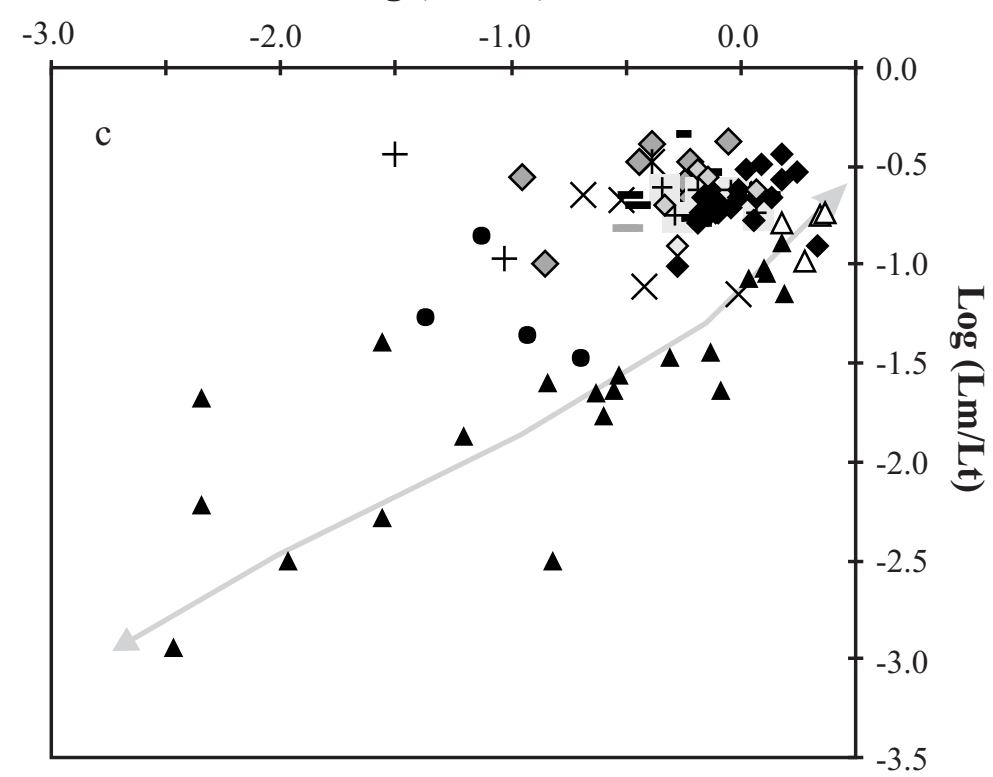

$\log (\operatorname{Lv} / \mathbf{L t})$

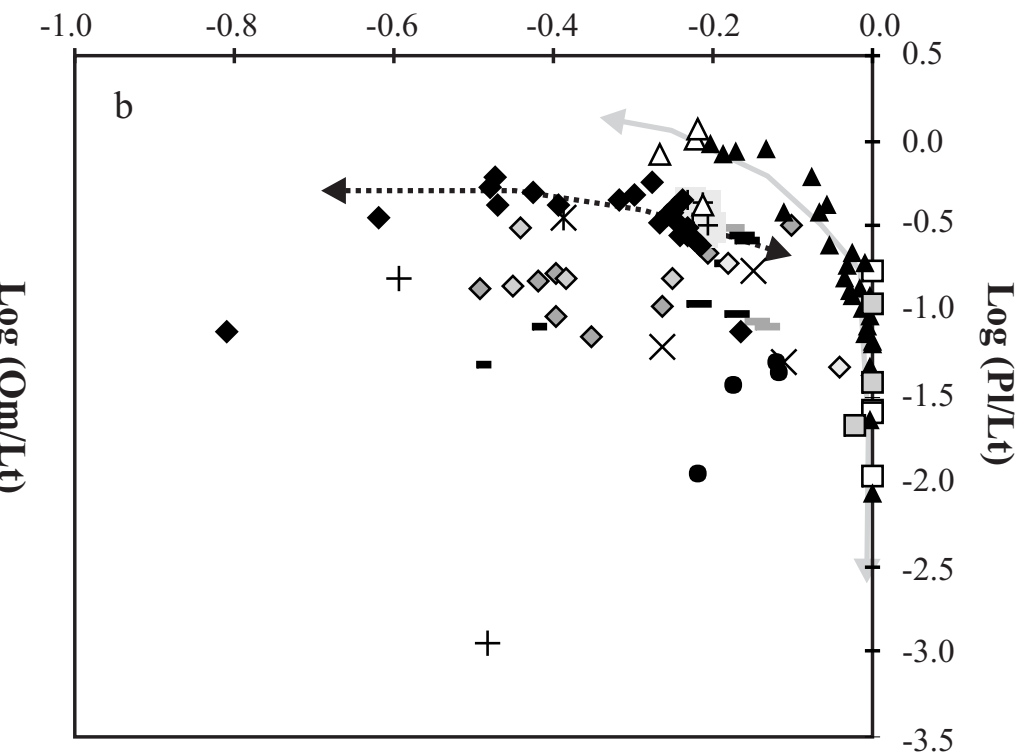

$\log (\mathrm{Qp} / \mathrm{Lt})$

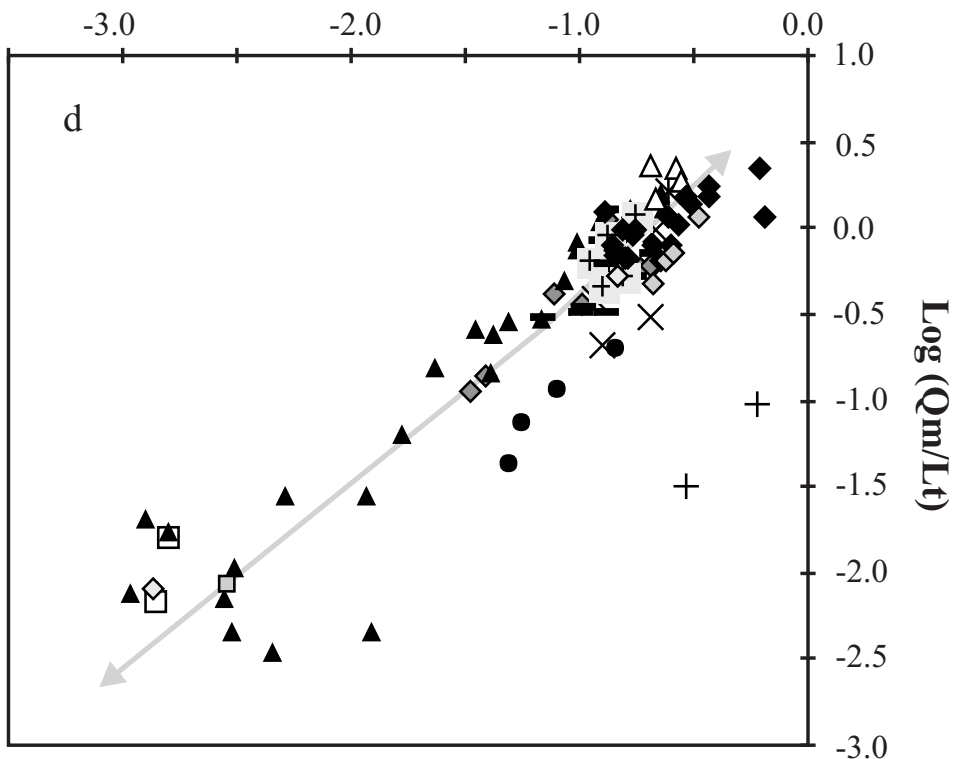




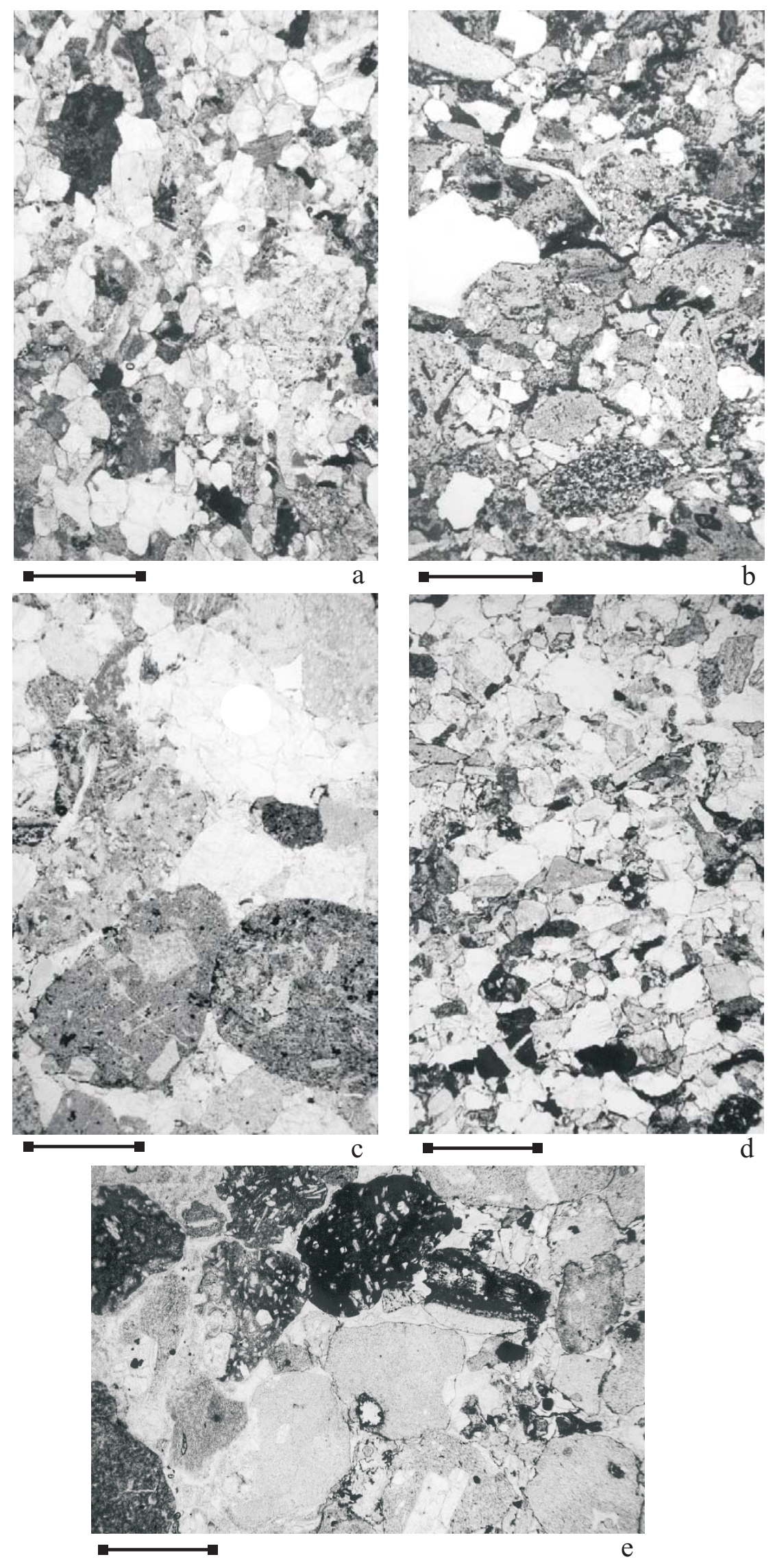




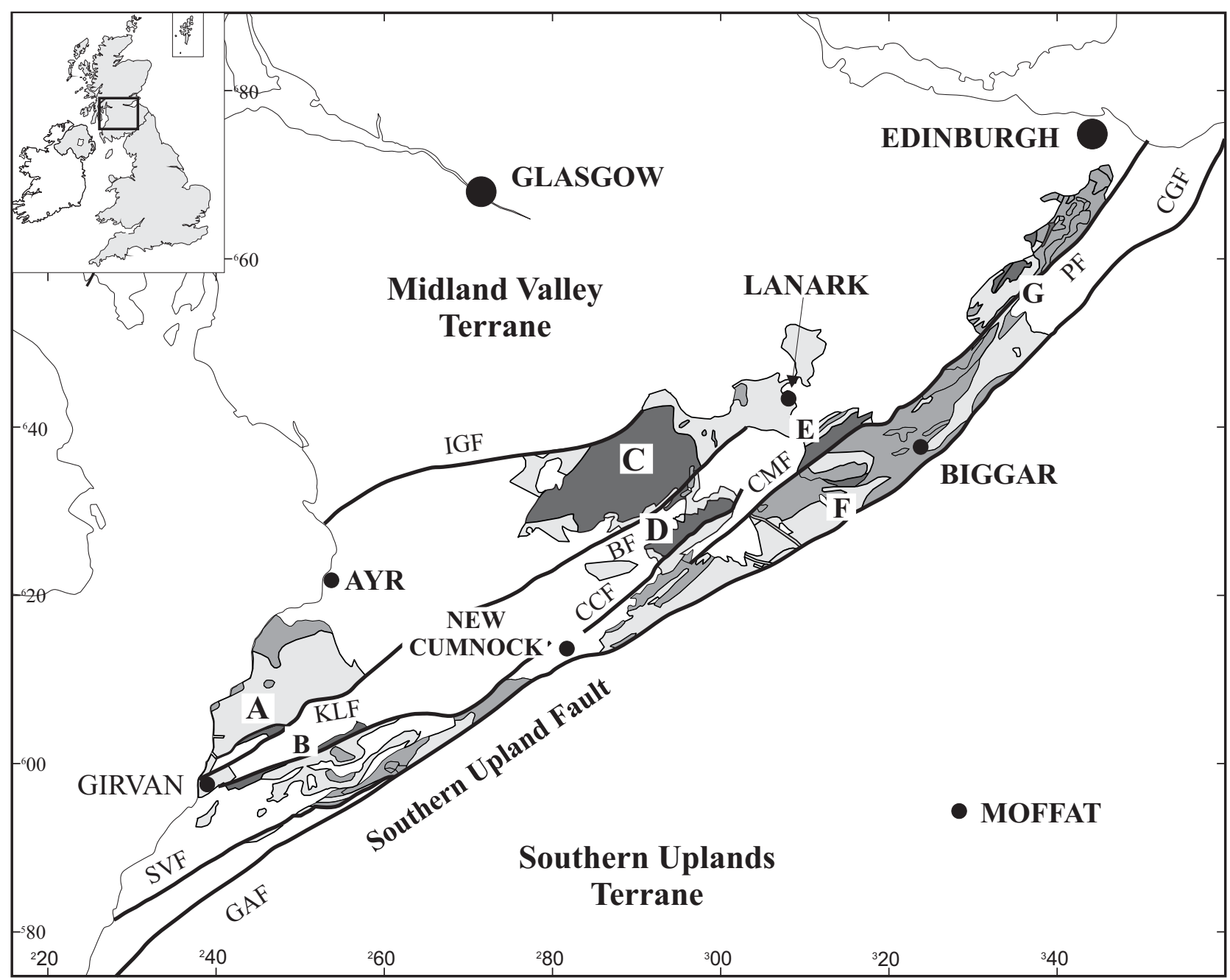

Midland Valley Silurian inliers Lanark Group sedimentary rocks Lanark Group igneous rocks

Silurian inliers: A, Craighead; B, Girvan Main; C, Lesmahagow; D, Hagshaw Hills; E, Carmichael; F, Eastfield; G, Pentland Hills (North Esk).

Faults: SVF, Stinchar Valley Fault; GAF, Glen App Fault; KLF, Kerse Loch Fault; BF, Bankend Fault; CCF, Carmacoup Fault; IGF, Inchgotrick Fault, CMF, Carmichael Fault; PF, Pentland Fault; CGF, Crossgatehall Fault. 


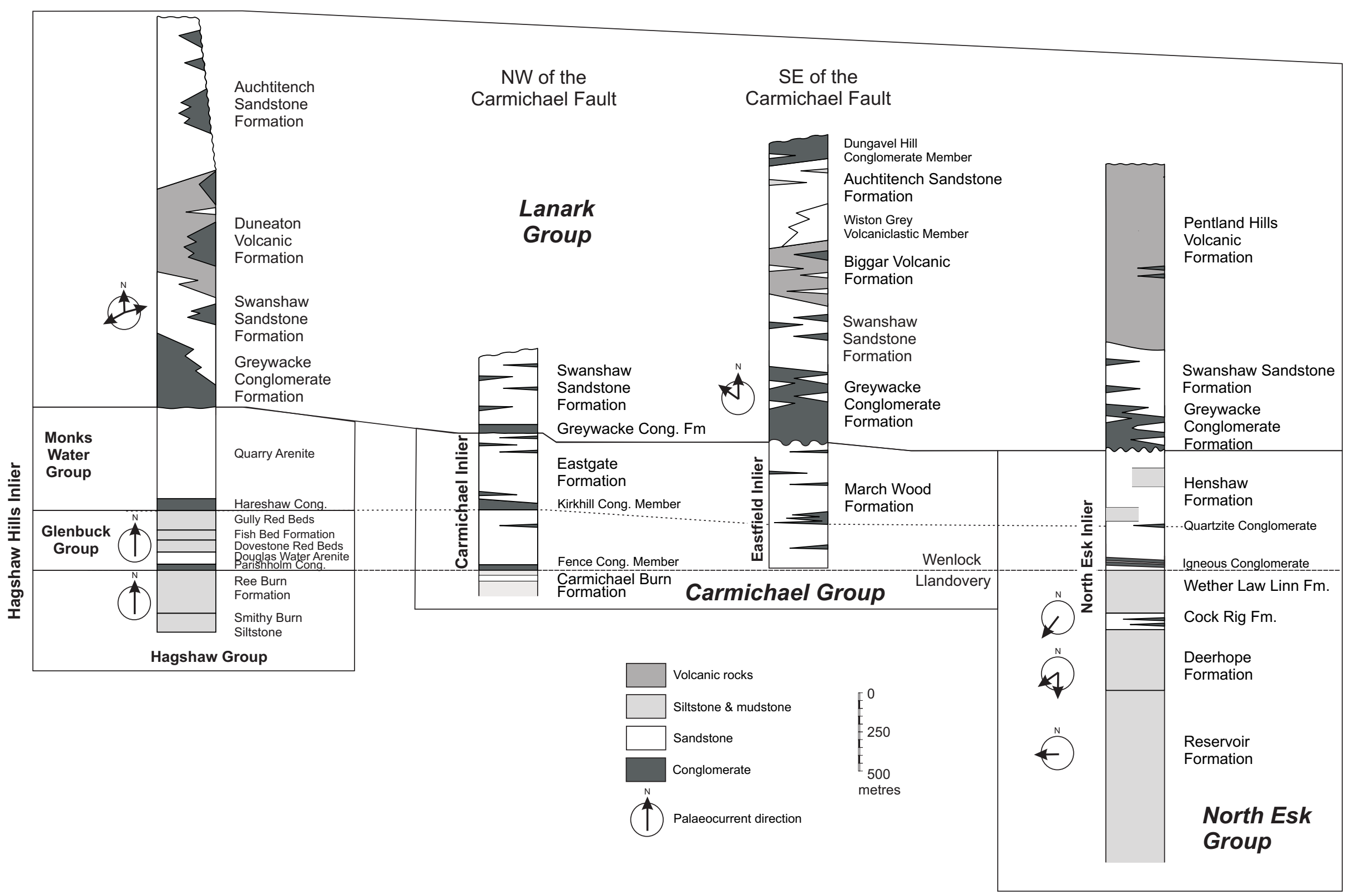



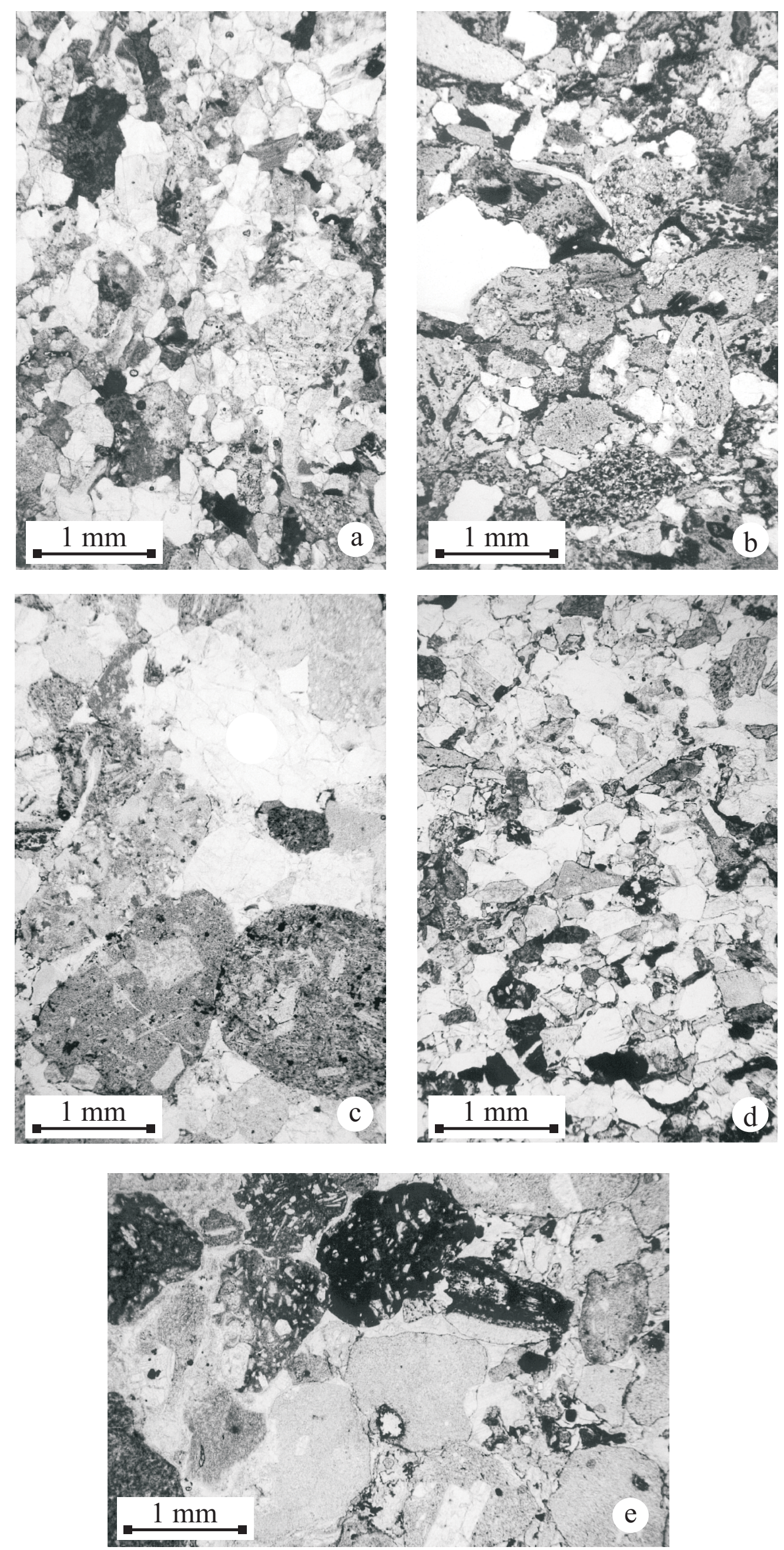

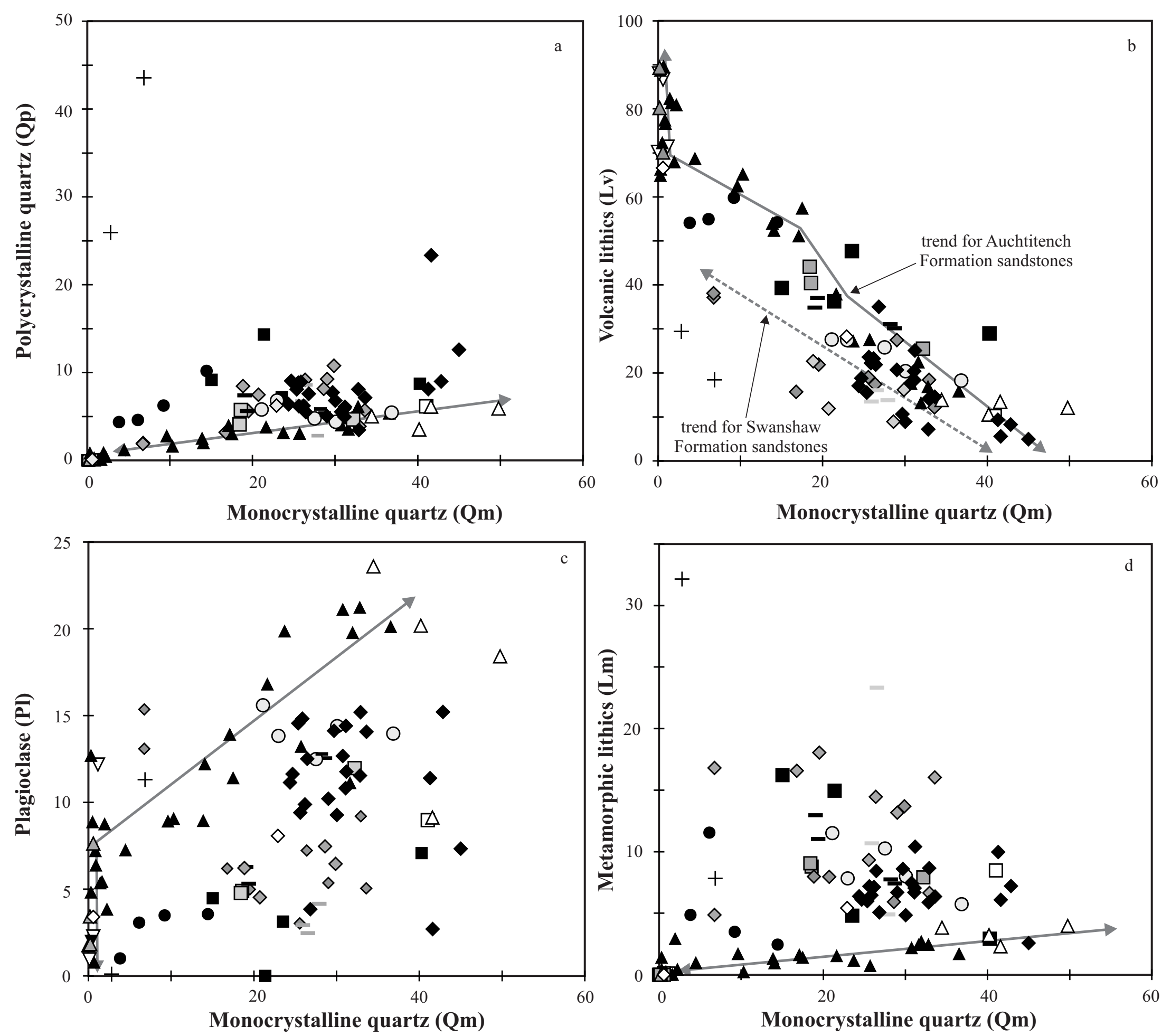

Pentland Hills North Esk inlier

Cock Rig Fm

$\square$ Henshaw Fm

- Igneous Conglomerate

+ Quartzite Conglomerate

- Greywacke Conglomerate Fm

Lanark district Carmichael inli

Eastgate Fm

- Greywacke Conglomerate Fm

- Swanshaw Sandstone Fm

Lanark district Eastfield inlier $\square$ March Wood Fm

- Greywacke Conglomerate Fm

$\triangle$ Wiston Grey Volcaniclastic Mbr

$\Delta$ Auchtitench Sandstone Fm

\section{New Cumnock district}

- Swanshaw Sandstone Fm

$\nabla$ Duneaton Volcanic Fm

$\triangle$ Auchtitench Sandstone Fm

\section{Hamilton district}

$\diamond$ Swanshaw Sandstone Fm

\section{Ayr district}

$\diamond$ Swanshaw Sandstone Fm 

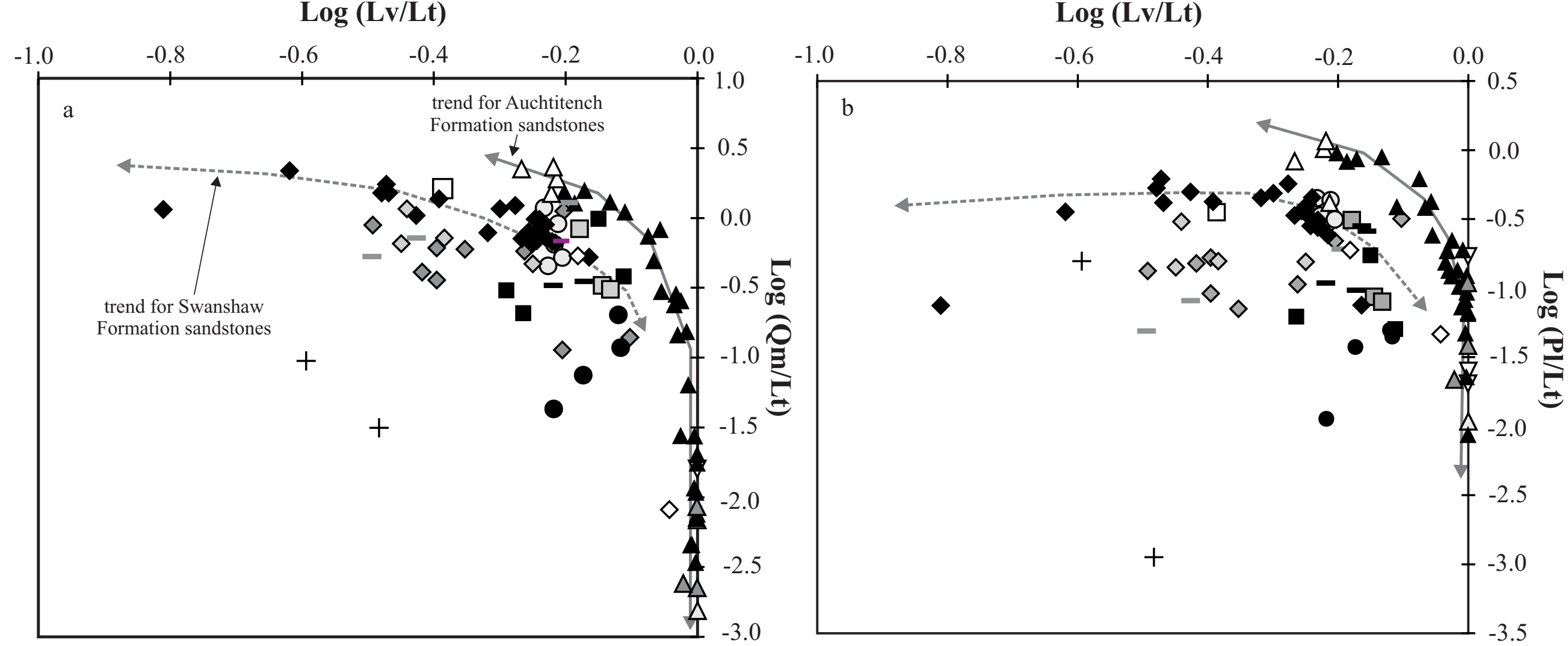

$\log (\mathbf{Q m} / \mathbf{L t})$

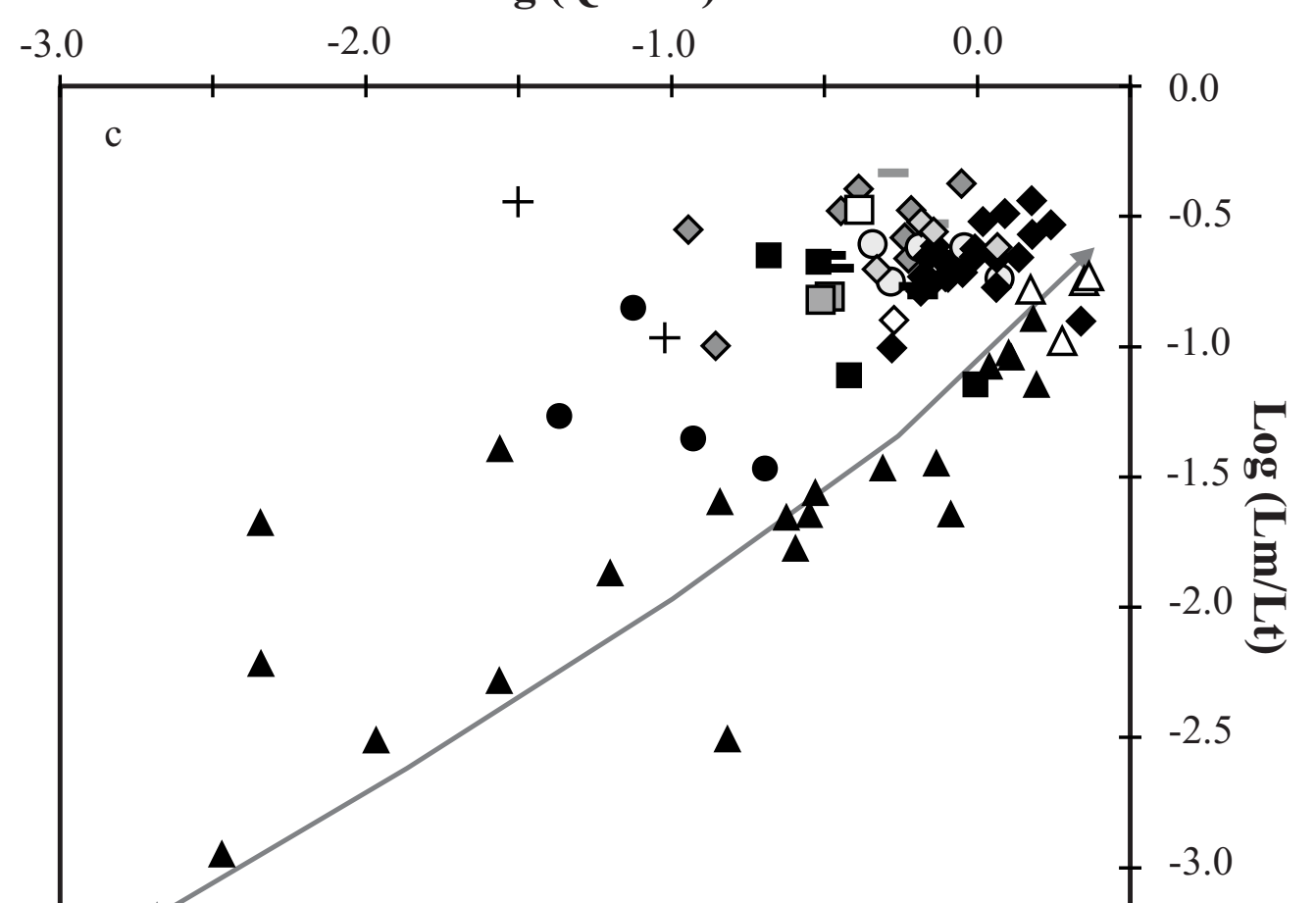

$\log (\mathbf{Q p} / \mathbf{L t})$

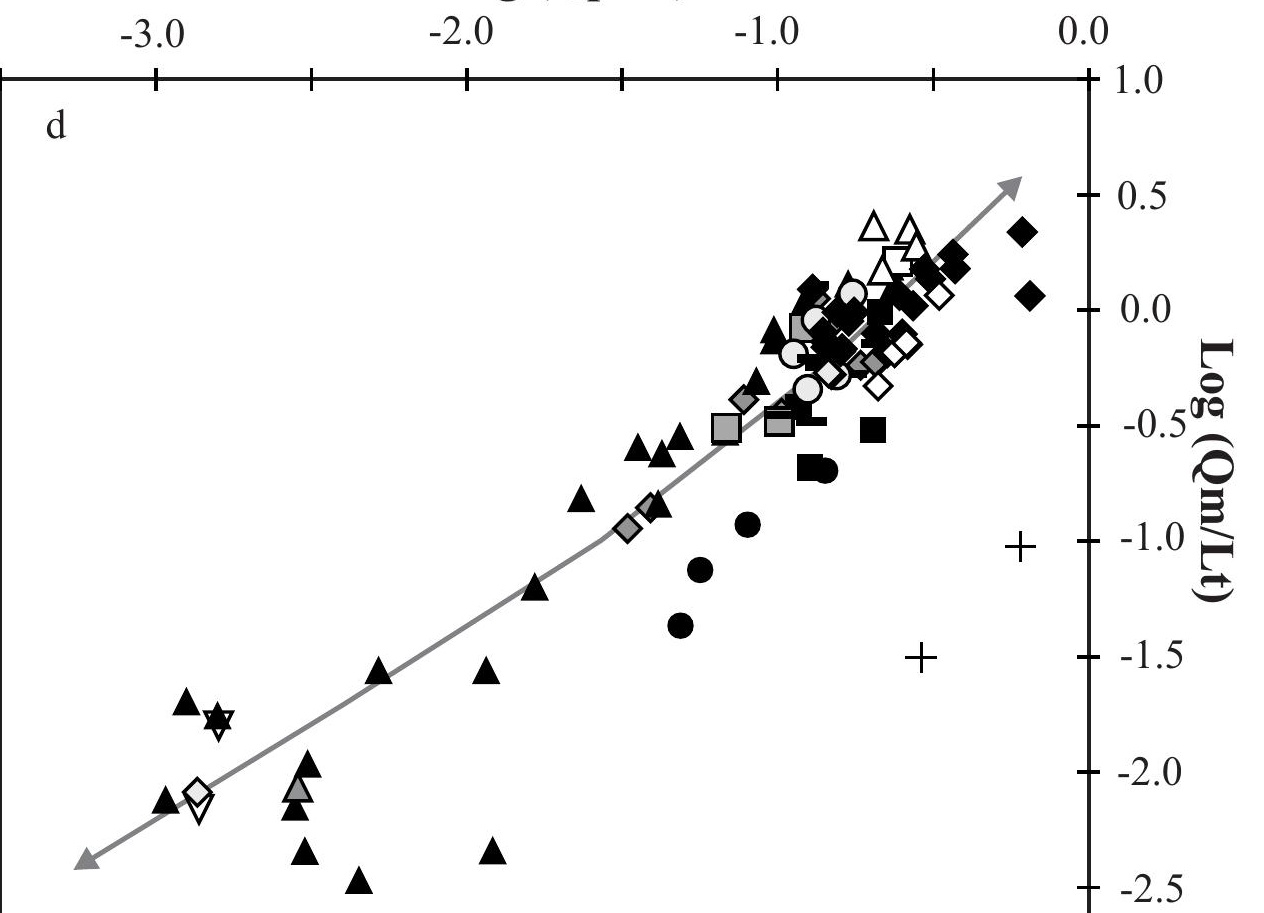



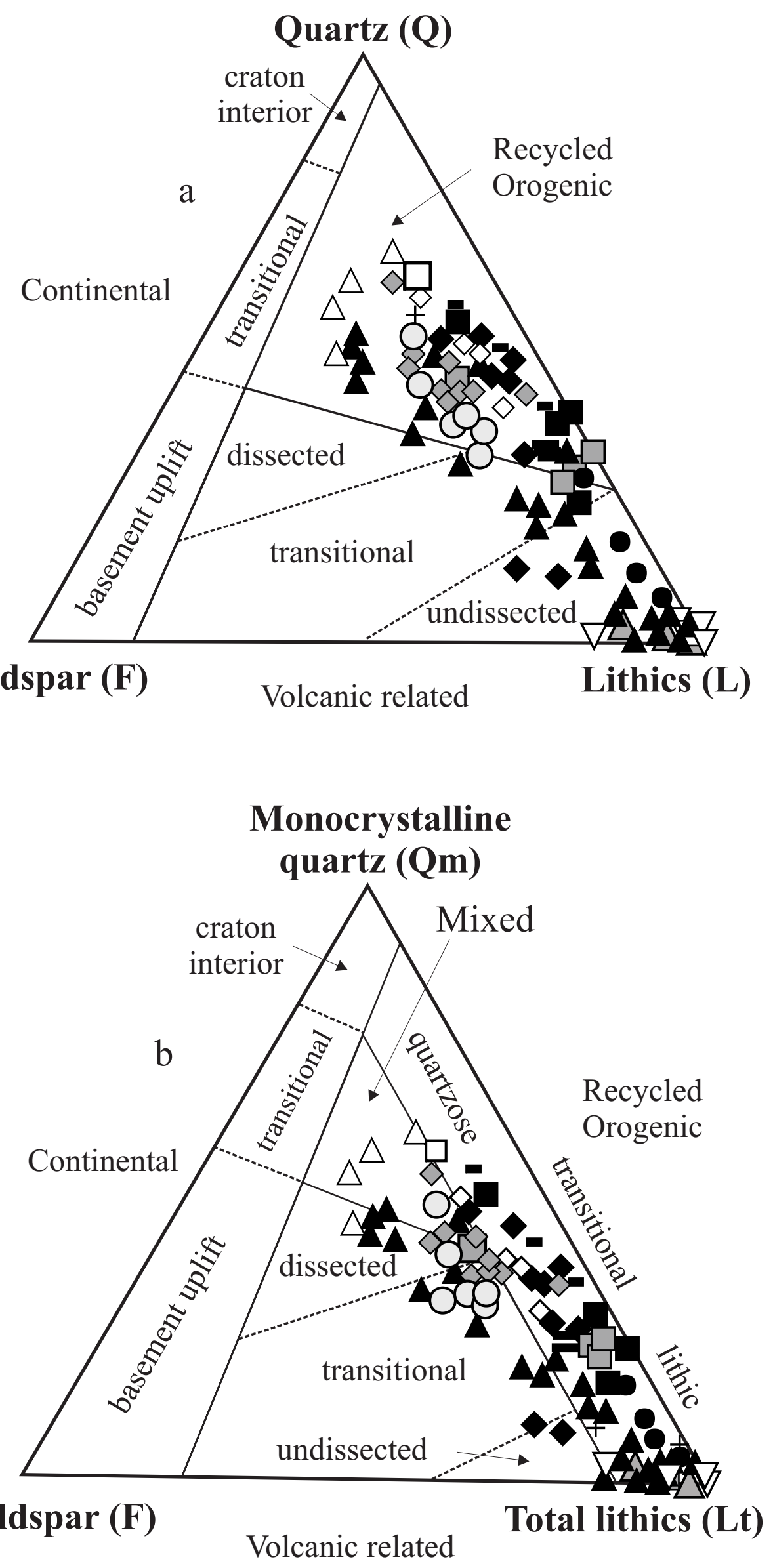
